\title{
La regulación de las telecomunicaciones y la Administración Local ${ }^{1}$
}

\author{
José María Souvirón Morenilla \\ Catedrático de Derecho Administrativo
}

Sumario $^{2}$ : I. LA REGULACIÓN DE LAS TELECOMUNICACIONES Y LA ACCIÓN DE LA ADMINISTRACIÓN PÚBLICA EN EL SECTOR. 1. De la publificación a la neorregulación. 2. El ámbito de aplicación de la LGTEL. 3. Los diversos planos de la acción de las Administraciones públicas en el ámbito de las telecomunicaciones. II. EL REGIMEN DE LA EXPLOTACIÓN DE LAS REDES Y PRESTACIÓN DE SERVICIOS DE TELECOMUNICACIONES. 1. El régimen general de las actividades. 1.1. Condiciones legales para operar en el sector. 1.2. Acceso a las redes y a la interconexión y numeración. 1.3. Mercados de referencia y operadores con poder significativo. 1.4. Régimen de los precios. 2. Los regímenes específicos. 2.1. Actividades configuradas como servicio público en sentido clásico. 2.2. El servicio universal como primera categoría de las obligaciones de servicio público. 2.3. Las llamadas otras obligaciones de servicio público. 3. Derechos y obligaciones de los operadores y usuarios y su garantía. 3.1. La posición jurídica de los operadores y los derechos de los usuarios. 3.2. Resolución de conflictos entre operadores y usuarios. 3.3. La garantía de los derechos de los usuarios como de carácter público. III. LA ACTIVIDAD PRESTACIONAL DE LAS CORPORACIONES LOCALES EN EL SECTOR DE LAS TELECOMUNICACIONES. 1. Las Administraciones como operadores de telecomunicaciones. 2. La posición singular de las Corporaciones locales. 3. Servicios de telecomunicaciones y servicios locales. IV. LOS ENTES LOCALES COMO TITULARES DE COMPETENCIAS DE REGULACIÓN CONCURRENTE CON LA DE LAS TELECOMUNICACIONES. 1. La concurrencia normativa y competencial y su coordinación. 2. Competencias sobre las infraestructuras. 2.1. Ocupación por los operadores del dominio público y la propiedad privada. a) El derecho de los operadores a la ocupación. b) El control preventivo y la normativa de los entes locales: límites. 2.2. La cooperación interadministrativa a efectos del despliegue de las redes de radiocomunicación. 3. Otras determinaciones de la normativa estatal con incidencia local: 3.1. El régimen de las ICT. 3.2. La protección frente a las emisiones e instalaciones radioeléctricas de comunicación. 4. Conclusión sobre las competencias de regulación de los entes locales. V. LA ADMINISTRACIÓN LOCAL Y LA GARANTÍA DE LOS USUARIOS DE TELECOMUNICACIONES. VI. UN APUNTE SOBRE ALGUNAS POSIBLES NOVEDADES DE FUTURO. 1. La revisión del marco regulatorio de las tele-

\footnotetext{
${ }^{1}$ El presente trabajo fue expuesto en la sesión del 21 de abril de 2006 del Seminario.de Derecho Local de la Federación de Municipios de Cataluña.

2 Abreviaturas: AER: Agencia Estatal de Radiocomunicaciones; BOE: Boletín Oficial del Estado; CE: Constitución Española; CMT: Comisión del Mercado de las Telecomunicaciones; ICT: Infraestructuras Comunes de Telecomunicación; LBRL: Ley de Bases de Régimen Local; LCAP: Ley de Contratos de las Administraciones Públicas; LGTEL: Ley General de Telecomunicaciones de 2003; LGTel: Ley General de Telecomunicaciones de 1998; LOT: Ley de Ordenación de las Telecomunicaciones de 1987; LSSI: Ley de Servicios de la Sociedad de la Información; REMERCADOS: Reglamento sobre los mercados de comunicaciones electrónicas, acceso a las redes y numeración; RSCL: Reglamento de Servicios de las Corporaciones Locales de 1955; RESERVICIOS: Reglamento sobre las condiciones para la prestación de servicios de comunicaciones electrónicas, el servicio universal y la protección de los usuarios; STC: Sentencia del Tribunal Constitucional; STS: Sentencia del Tribunal Supremo.
} 
comunicaciones. 2. La reforma de la legislación básica de régimen local y las reformas estatutarias.

\section{LA REGULACIÓN DE LAS TELECOMUNICACIONES Y LA ACCIÓN DE LA ADMINISTRACIÓN PÚBLICA EN EL SECTOR}

Nuestra vigente regulación de las telecomunicaciones, presidida por la Ley de 3 de noviembre de 2003, General de Telecomunicaciones (LGTEL), culmina hasta la fecha una evolución normativa que ha llevado desde la secular publificación del sector a su actual neorregulación. Como es lógico, este cambio en las claves del régimen jurídico de las telecomunicaciones no ha podido menos que afectar de raíz al papel a desempeñar en el sector por la Administración, por las distintas Administraciones públicas, papel abierto así, en ese nuevo marco regulatorio, a hipótesis distantes de la tradicional acción de aquéllas y bien sugerentes, por lo demás, a la vista de la creciente relevancia social y económica de este tipo de actividad.

\section{De la publificación a la neorregulación}

En efecto, hasta la Ley General de Telecomunicaciones de 1998 (LGTel), antecedente inmediato de la hoy vigente del mismo nombre, nuestro ordenamiento - prácticamente sin solución de continuidad desde finales del siglo XIX- configuró las telecomunicaciones como un sector de actividad reservado en monopolio «de iure», es decir, con reserva de su titularidad jurídica, al sector público estatal, cualquiera que luego fuera el modo de su desarrollo por éste, en gestión directa por la propia Administración o indirecta concesional, en este caso también con su explotación efectiva en monopolio. A este modelo tradicional, y como última expresión del mismo, respondía la Ley de Ordenación de las Telecomunicaciones de 1987 (LOT), que tomaba como título de intervención pública a tal fin - además del dominio público radioeléctrico- el «servicio público» en el sentido estricto de este concepto (es decir, la reserva de la actividad al Estado conforme a lo previsto por el artículo 128.2 CE), calificación ésta aplicada en efecto por la LOT al conjunto de las telecomunicaciones.

Pero recién aprobada la LOT tomó cuerpo en la Unión Europea una decidida política comunitaria sobre las telecomunicaciones dirigida a su progresiva liberalización y desarrollo en libre competencia que se plasmó en las correspondientes Directivas (aprobadas entre 1988 y 1997). La incorporación de ese Derecho comunitario derivado a nuestro ordenamiento interno se produjo inicialmente de modo sólo incipiente y fragmentario, y ya con carácter general por el Real Decreto Ley 6/1996, de liberalización de las telecomunicaciones, luego convertido en Ley 12/1997, de la misma 
LA REGULACIÓN DE LAS TELECOMUNICACIONES Y LA ADMINISTRACIÓN LOCAL

denominación ${ }^{3}$. A partir de ese momento, las medidas para la plena liberalización y puesta en práctica de la competencia efectiva en el sector antes de diciembre de 1998 - fecha prefijada por la Unión Europea- se sucedieron, para culminar con la Ley General de Telecomunicaciones de 24 de abril de 1998.

Esta Ley (modificada luego parcialmente por los Reales Decretos Leyes 6/1999, 16/1999 y 7/2000, con el fin de intensificar la competencia en el sector), y como tributaria de la neorregulación comunitaria, instituyó un modelo jurídico opuesto al tradicional de nuestro país: la explotación de redes y la prestación de servicios de telecomunicaciones no iban ya a estar reservadas a la titularidad del sector público, sino liberalizadas para su desarrollo en el mercado y en libre competencia, aunque - eso sí- sujetas a una «regulación» basada en la necesaria obtención por los operadores de una autorización general o una licencia individual a otorgar por la Administración, así como a la eventual imposición a los operadores de «obligaciones de servicio público», entre ellas, el llamado «servicio universal» (instituciones éstas que luego abordaremos).

Pues bien, el 3 de noviembre de 2003 se promulga una nueva Ley General de Telecomunicaciones (LGTEL), la actualmente vigente, con el fin de ajustar nuestro ordenamiento al llamado «nuevo marco para las comunicaciones electrónicas» (integrado por 6 nuevas Directivas y una Recomendación) aprobado por la Unión Europea en 2002 con el fin de consolidar y profundizar en los principios ya consagrados por la normativa comunitaria anterior, y entre cuyos aspectos más novedosos podemos destacar: 1) La efectiva liberalización de la explotación de redes y prestación de servicios de telecomunicaciones, pues ahora, además de que las actividades en autoprestación son enteramente libres, las llevadas a cabo a favor de terceros, las actividades comerciales, no van a requerir más que su notificación a la Comisión del Mercado de las Telecomunicaciones (CMT). 2) El nuevo mecanismo para asegurar que las actividades se desarrollan en libre competencia efectiva que constituye la definición y supervisión por la CMT de los llamados «mercados de referencia» y la eventual imposición de obligaciones específicas a los «operadores con poder significativo» en tales mercados. 3) La profundización, con el objetivo de garantizar los intereses colectivos, en las determinaciones regulatorias de las «obligaciones de servicio público» y el «servicio universal».

Analizaremos a lo largo de estas páginas estos apartados característicos de la actual regulación de las telecomunicaciones, presidida, además de por la LGTEL, por estos dos fundamentales reglamentos para su desarrollo: el

\footnotetext{
${ }^{3}$ Precisemos, no obstante, que estas dos últimas normas, más que una auténtica liberalización —o sea, la despublificación de las actividades-, lo que establecieron fue la apertura de las telecomunicaciones a su desarrollo en competencia mediante la concurrencia progresiva de varios operadores, pero en todo caso todavía como concesionarios de una actividad aun publificada bajo esa clave del servicio público en sentido estricto.
} 
Reglamento sobre los mercados de comunicaciones electrónicas, acceso a las redes y numeración (en adelante REMERCADOS), aprobado por Real Decreto 2296/2004, de 10 de diciembre, y el Reglamento sobre las condiciones para la prestación de servicios de comunicaciones electrónicas, el servicio universal y la protección de los usuarios (en adelante RESERVICIOS), aprobado por Real Decreto 424 / 2005, de 15 de abril. Pero antes, conviene acotemos el ámbito de aplicación de la LGTEL.

\section{El ámbito de aplicación de la LGTEL}

Dictada al amparo de la competencia estatal exclusiva en esta materia (art. 149.1.21 CE), la LGTEL regula las telecomunicaciones, concepto éste definido en el Anexo II de la Ley como «toda transmisión, emisión o recepción de signos, señales, escritos, imágenes, sonidos o informaciones de cualquier naturaleza por hilo, radioelectricidad, medios ópticos u otros sistemas electromagnéticos». Ahora bien, es preciso hacer las siguientes precisiones:

$1^{\mathrm{a}}$ ) El concepto de «telecomunicaciones» utilizado por la LGTEL para definir su ámbito de aplicación es más amplio que el de «comunicaciones electrónicas», que es el utilizado por el marco regulador comunitario de 2002. Porque, como aclara la E. de M. de la LGTEL, ésta ha querido regular, al amparo del art. 149.1.21 CE, todo el ámbito de las telecomunicaciones, incluyendo así también, además de las «comunicaciones electrónicas», otros aspectos no estrictamente atinentes a éstas y por ello no abordados por el marco comunitario.

$2^{\mathrm{a}}$ ) La LGTEL regula sólo y exclusivamente el sector de las telecomunicaciones («transmisión, emisión, recepción...»). Por ello excluye expresamente de su ámbito de aplicación «el régimen aplicable a los contenidos de carácter audiovisual transmitidos a través de las redes, así como el régimen básico de los medios de comunicación social de naturaleza audiovisual a que se refiere el artículo 149.1.27 CE» (art. $1^{\circ} .2$ LGTEL). Así pues, quedan excluídos de la LGTEL los contenidos audiovisuales y el régimen básico de los medios audiovisuales, pero no las redes de telecomunicaciones utilizadas a tal fin, las cuales sí se sujetarán a la LGTEL.

$3^{\text {a) }}$ Queda asimismo excluida del ámbito de aplicación de la LGTEL «la regulación de los servicios que suministren contenidos transmitidos mediante redes y servicios de comunicaciones electrónicas, de las actividades que consistan en el ejercicio del control editorial sobre dichos contenidos y los servicios de la Sociedad de la Información, regulados en la Ley 34/2002, de 11 de julio, de los servicios de la sociedad e la información y de comercio electrónico, que no consistan, en su totalidad o principalmente, en el transporte de señales a través de comunicaciones electrónicas» (art. $1^{\circ} .2$, párrafo $2^{\circ}$ LGTEL). Con ello la prestación de ese tipo de servicios sobre las redes de telecomuni- 
caciones, si los mismos no consisten total o principalmente en el transporte de señales a través de aquéllas (por ejemplo, el suministro de contenidos en forma de páginas en Internet) se sujetarán a la LSSI y no a la LGTEL, y, por el contrario, si se trata de servicios consistentes total o principalmente en el transporte de señales a través de las redes de telecomunicación (por ejemplo, el servicio de acceso a Internet), entonces sí se sujetarán a la LGTEL.

El panorama expuesto es el que se deriva de las previsiones de la LGTEL y, en suma, de la legislación estatal. Recientes disposiciones de las Comunidades Autónomas han añadido, sin embargo, a la cuestión una nueva complejidad. Es el caso de la Ley 22/ 2005, de 29 de diciembre, de la comunicación audiovisual de Cataluña. Porque la misma, en ese contexto y ámbito competencial del audiovisual que acota su rúbrica - y no el de las telecomunicaciones, ámbito éste de la exclusiva competencia del Estado-, regula, no obstante, determinadas actividades de telecomunicación en la medida que «participan en la prestación de los servicios de comunicación audiovisual, principalmente los operadores de redes, los servicios de comunicación electrónica y los operadores de servicios de acceso condicional». Y es que dicha Ley catalana, aunque reconoce se trata de actividades de telecomunicación, pese a ello las sujeta a su propio ámbito de aplicación ( «Si bien están sujetas al régimen jurídico establecido por la legislación de telecomunicaciones - dice su E. de M. - han de respetar las disposiciones establecidas en esta ley en cuanto al contenido que transmitan al público»), regulando, en efecto, (arts. 2 y 65) determinadas obligaciones de transmisión, distribución, etc. de tales operadores de redes.

Esa expansión autonómica hacia la materia de las telecomunicaciones — reiteramos, como tal exclusiva del Estado ex art. 149.1.21 CE- puede apreciarse incluso en un apartado tan característico de dicha materia como el dominio público radioeléctrico, al atribuir la Ley catalana del audiovisual a la Generalidad competencias sobre su planificación y gestión y de participación en la planificación estatal (arts. 17 a 22). Ello con el argumento expreso, y tras reconocer esa exclusividad estatal de la materia, de que ésta «ha de hacerse compatible con la competencia audiovisual de la Generalidad» (cf. la E. de M.) y de que el espacio radioeléctrico es «un elemento instrumental» de la competencia audiovisual (art. 17). Así pues, una expansión competencial de la Comunidad Autónoma un tanto discutible que, no obstante, pudiera hallar cierto fundamento en alguna jurisprudencia constitucional antecedente que, como criterio para la ubicación de una actividad en el artículo 149.1. $21 \mathrm{CE}$ (telecomunicaciones, competencia exclusiva del Estado) o en el 149.1. 27 (medios audiovisuales, compartida entre el Estado y las Comunidades Autónomas), evocó el carácter predominante que en esa actividad alternativamente tuvieran los aspectos técnicos (artículo 149.1. 21) o los de la comunicación y los contenidos audiovisuales (artículo 149.1. 27), e incluso resultar coincidente con algunas de las previsiones del Anteproyecto de Ley General Audiovisual que viene preparando el Estado. 


\section{Los diversos planos de la acción de las Administraciones públicas en el ámbito de las telecomunicaciones}

En todo caso y según decíamos, la evolución del régimen de las telecomunicaciones, desde su publificación a su liberalización y desarrollo en el mercado y en libre competencia, no ha podido menos que afectar al papel a desempeñar por la Administración pública, por definición ya muy diferente del que bajo el tradicional marco normativo del sector aquélla — en esencia la Administración estatal- cumplía en tanto que titular monopolista del mismo. Un distinto papel que, en la línea inaugurada por la LGTel de 1998, se ha adensado con la LGTEL de 2003 un tanto más teniendo en cuenta uno de los principios proclamados por la E. de M. de esta última, el de la «mínima intervención de la Administración pública». Lo que no excluye que esa intervención —ahora no sólo la de la Administración del Estado- se exprese o pueda expresarse a través de formas de acción diversas más allá de la unidimensional antigua intervención monopolista de aquélla; en concreto en los siguientes planos:

a) En primer lugar, la función «reguladora» de las telecomunicaciones, atribuída por la Ley (sobre la base de la competencia exclusiva en la materia reconocida al Estado por el art. 149.1.21 CE) a la Administración General del Estado y a determinados organismos públicos de ésta (es lo que la Ley denomina «la Administración de las telecomunicaciones» y a efectos del Derecho comunitario europeo califica de «Autoridad Nacional de Reglamentación»). En concreto, el Gobierno de la Nación, los órganos superiores y directivos del Ministerio de Industria, los del Ministerio de Economía en materia de regulación de precios, la Comisión del Mercado de las Telecomunicaciones (CMT) y la Agencia Estatal de Radiocomunicaciones (AER), además del Consejo Asesor de las Telecomunicaciones y de la Sociedad de la Información como órgano consultivo.

A cada uno de estos órganos y organismos le atribuye la Ley las correspondientes competencias normativas, administrativas, de supervisión e inspección, sancionadoras y consultivas (en el caso de la AER, de carácter especializado como es la «ejecución de la gestión del dominio público radioeléctrico»). En todo caso, y como puede apreciarse, sólo a la Administración del Estado le corresponde la competencia reguladora sobre el sector de las telecomunicaciones como tal.

b) Pero, en segundo lugar, la actuación de las Administraciones públicas - en este plano no sólo la Administración General del Estado, sino también las demás Administraciones- se extiende asimismo a otros ámbitos funcionales o competenciales distintos de la regulación: así, su posible actuación prestacional como operadores de telecomunicaciones, el ejercicio por las distintas Administraciones de competencias concurrentes o con incidencia en las telecomunicaciones, o su función como garantes de la adecuada prestación de los servicios de telecomunicación. 
El propósito central de estas páginas es precisar, en ese contexto, el papel a desempeñar por las Administraciones locales en el ámbito de las telecomunicaciones. Pero a tal fin resulta del todo necesario, como hacemos a continuación, pasar revista previamente de manera sintética a la regulación de las telecomunicaciones.

\section{EL RÉGIMEN DE LA EXPLOTACIÓN DE LAS REDES Y PRESTACIÓN DE SERVICIOS DE TELECOMUNICACIONES}

\section{El régimen general de las actividades}

\subsection{Condiciones legales para operar en el sector}

El régimen general de las telecomunicaciones (explotación de redes, prestación de servicios) es un régimen de libertad y libre competencia en el marco de la Ley. Así lo proclama la LGTEL: «Las telecomunicaciones son servicios de interés general que se prestan en régimen de libre competencia» $\left(\operatorname{art.} 2^{\circ} .1\right) \ldots$ «La explotación de las redes y la prestación de los servicios de telecomunicaciones electrónicas se realizará en régimen de libre competencia sin más limitaciones que las establecidas en esta Ley y su normativa de desarrollo» (art. $5^{\circ} .1$ ). «Limitaciones», es decir, régimen legal, constituído en esencia por:

$1^{\circ}$ Los requisitos exigidos para poder explotar redes y prestar servicios de telecomunicaciones, en concreto: poseer la nacionalidad comunitaria o de un Estado tercero con convenio internacional con España, así como la previa notificación fehaciente por el operador a la CMT — salvo en las actividades en autoprestación en que no será necesaria - de la actividad que va a realizar (la CMT sólo podrá rechazar dicha notificación de manera reglada y motivada y en el plazo de 15 días) y su posterior inscripción en el Registro de operadores de la CMT.

$2^{\circ}$ Las condiciones para el desarrollo de dichas actividades, que el RESERVICIOS (arts. 15 y ss.) ha sistematizado detallando los derechos que en general corresponden a los operadores (en relación con la interconexión, la numeración, el uso del dominio público radioeléctrico y la ocupación del dominio público y la propiedad privada) y sus obligaciones; tanto generales (contribuir a la financiación del servicio universal, garantizar la interoperabilidad de los servicios, la protección de los datos personales, satisfacer los derechos de los usuarios, suministrar a las Autoridades de reglamentación la información que éstas motivada y proporcionadamente, y bajo reserva de confidencialidad comercial, etc., les requieran), como las específicas de los operadores de redes, en particular las de los operadores de redes telefónicas y del servicio telefónico. 
$3^{\circ}$ ) Todo ello sin perjuicio de que en algunos apartados concomitantes los operadores de telecomunicaciones deban sujetarse a la correspondiente normativa específica y obtener el título habilitante que ésta prevea. Es el caso, por ejemplo, del uso del dominio público radioeléctrico ${ }^{4}$ o de la ocupación del dominio público o la propiedad privada (art. $5^{\circ} .2$ LGTEL), apartado este último que abordamos con detalle más adelante.

\subsection{Acceso a las redes y a la interconexión y numeración}

Un sistema liberalizado y de libre competencia en la explotación de las redes y la prestación de servicios de telecomunicaciones exige, por razones puramente técnicas, la interconexión de aquéllas y, en su caso, el acceso recíproco a todas ellas de los operadores actuantes. Así lo garantiza la LGTEL (art. 11.1): los operadores de redes deben satisfacer la petición de acceso e interconexión de otros operadores, negociando el oportuno acuerdo al respecto conforme al principio de igualdad de trato y bajo supervisión de la CMT, la cual puede imponer a los operadores obligaciones y condiciones a tal fin, particularmente a los operadores con poder significativo en los mercados de referencia, así como resolver los conflictos que sobre la interconexión se produzcan entre los operadores.

Por otra parte, el desarrollo de los servicios de comunicaciones electrónicas (de telecomunicaciones) disponibles al público requiere de un sistema de números y direcciones que permitan su efectiva prestación, que es efectivamente regulado por la LGTEL (arts. 16 y ss.) y el RESERVICIOS (art. 26 y ss.) en los siguientes términos: carácter público de los recursos de numeración y direccionamiento; su utilización conforme a lo que dispongan los correspondientes Planes Nacionales que ha de aprobar el Gobierno (el Plan Nacional de Numeración telefónica fue aprobado por el propio REMERCADOS); y su gestión básicamente por la CMT. A los operadores les serán asignados por la CMT los correspondientes números y los usuarios tienen derecho al acceso a la numeración y a los servicios de cualquier proveedor interconectado - a través del correspondiente código de selección de operador-, así como a la conservación de sus números con independencia del operador con quien contrate el servicio.

\footnotetext{
${ }^{4}$ El uso del dominio público radioeléctrico, atribuída su titularidad y gestión por la LGTEL al Estado, bajo el régimen definido por aquélla (arts. 43-45) y su desarrollo reglamentario (Reglamento del dominio público radioeléctrico, aprobado por Orden de 9 de marzo de 2000, y vigente tras la LGTEL con las modificaciones introducidas en él por el Real Decreto 424/ 2005, de 15 de abril), admite las modalidades de uso común, que no precisa título habilitante; uso especial, no privativo y que requiere autorización; y uso privativo, que requerirá concesión si el uso se vincula a servicios a prestar a terceros, autorización si es para autoprestación por los particulares, o afectación demanial si para autoprestación por una Administración pública (art. 44 LGTEL).
} 


\subsection{Mercados de referencia y operadores con poder significativo}

Pero asegurado en los términos expuestos el funcionamiento global del sistema de telecomunicaciones - funcionamiento en unidad, no obstante la pluralidad de operadores y la libre competencia-, la garantía de ésta última se manifiesta de manera típica en el estatuto de obligaciones que con dicho objetivo pueden imponerse a los llamados «operadores con poder significativo» en los distintos mercados de telecomunicaciones. Todo ello conforme al siguiente mecanismo.

$\left.1^{\circ}\right)$ La CMT, teniendo en cuenta los correspondientes Directrices de la Unión Europea, ha de definir, mediante resolución publicada en el BOE, los llamados «mercados de referencia» — al por mayor y al por menor- relativos a redes y servicios de telecomunicaciones, así como el ámbito geográfico de los mismos, cuyas características puedan justificar la imposición, en su caso, de obligaciones específicas a los operadores con poder significativo en dichos mercados. Cada mercado de referencia abarcará todos los servicios de comunicaciones electrónicas que sean suficientemente intercambiables o sustituibles (por la naturaleza de sus prestaciones, sus precios o su uso previsto, o por las condiciones de competencia o la estructura de oferta y demanda existente en cada mercado) (cf. art. 10 y ss. LGTEL y $2^{\circ}$ y ss. REMERCADOS).

$2^{\circ}$ ) Definidos tales mercados, como mínimo cada dos años, la CMT ha de realizar asimismo un análisis de cada uno de ellos con el fin de determinar si se desarrollan en un entorno de competencia efectiva. A la vista de los resultados de ese análisis, que se harán públicos, si la CMT considera que no existe competencia efectiva, identificará y hará públicos el operador u operadores que poseen poder significativo en dicho mercado, es decir, «cuando un operador individual o conjuntamente con otros, disfruta de una posición equivalente a una posición dominante, esto es, una posición de fuerza económica que permite que su comportamiento sea, en media apreciable, independiente de los competidores, los clientes y en última instancia los consumidores que sean personas físicas».

$3^{\circ}$ ) La consecuencia directa de esa identificación de los operadores con poder significativo es la imposición a los mismos por la CMT de las correspondientes «obligaciones específicas» (obligaciones que podrán serles suprimidas si de un ulterior análisis del mercado resultara que éste se desarrolla ya en un entorno de competencia efectiva) ${ }^{5}$.

\footnotetext{
${ }^{5}$ Estas «obligaciones específicas», que forman parte del régimen general (y no son por tanto excepciones al mismo, como lo son las llamadas «obligaciones de servicio público» a que después nos referiremos) incluyen, según lo concreta el REMERCADOS (art. $6^{\circ}$ y ss):

a) En los mercados al por mayor (entre operadores), hacer pública una llamada «oferta de referencia» sobre acceso e interconexión con sus redes, con la suficiente información al respecto, incluídos los precios aplicables a cada una de las componentes de la oferta, y no discriminatoria en la oferta entre operadores; la separación de cuentas en las actividades de acceso e interconexión; y sujetarse a las medi-
} 
Esta supervisión por la CMT — para asegurar la competencia efectivade los mercados de referencia constituye el nuevo y fundamental instrumento regulatorio de la LGTEL, y su relevancia es evidente dadas las obligaciones a que pueden quedar sujetos los operadores con poder significativo en cada uno de dichos mercados, en particular en materia de precios. No menos evidente es también su complejidad al requerir la puesta en práctica por la CMT de la serie de cometidos secuenciales que hemos reseñado (definición de los mercados de referencia, su análisis respectivo, la identificación, en su caso, de los operadores con poder significativo, y la adopción de las medidas relativas a la imposición, mantenimiento, modificación o supresión de la citadas obligaciones específicas de tales operadores), y todo ello a través de los oportunos procedimientos de información y consulta públicas ${ }^{6}$. En cualquier caso, cuando escribimos estas páginas la CMT ha concluído ya el análisis de 14 de los 18 mercados (7 minoristas y 11 mayoristas) en que para dicho análisis ha quedado dividido el sector.

\subsection{Régimen de los precios}

En principio, en un régimen liberalizado de las actividades económicas a desarrollar en libre competencia los precios por su prestación no han de estar regulados. Y así lo dispone, en efecto, la LGTEL, según la cual, una vez fijados por la CMT los mercados de referencia, a partir de ese momento, los precios no estarán regulados con carácter general. Siempre, claro está, que en el mercado de que se trate haya competencia efectiva, pues en otro caso ya hemos visto que la CMT puede imponer a los operadores con poder significativo en ese mercado medidas para el control de sus precios; y todo ello además sin perjuicio de lo establecido al respecto, según veremos, para el servicio universal (téngase en cuenta que esas medidas de control de precios

das de control de precios que le imponga la CMT así como orientar los mismos en función de los costes de producción más una tasa razonable de rendimiento de la inversión.

b) En los mercados al por menor: obligaciones en materia de realización de las llamadas de telefonía fija mediante selección de operador llamada a llamada y por preselección; de control de precios mediante diversas medidas a imponer por la CMT (límites máximos de precios en los servicios al público, promediación geográfica de precios, control de tarifas individuales, orientación de las tarifas a costes o a precios de mercado comparables), todo ello cuando no haya competencia efectiva en el mercado correspondiente (art. 19 REMERCADOS) y exigencia en ese caso de contabilidad de costes; además de las obligaciones particularmente aplicables en el caso de la prestación del servicio de líneas susceptibles de arrendamiento

\footnotetext{
${ }^{6}$ De ahí que la LGTEL (disp. transitoria $1^{\mathrm{a}}$ LGTEL) dispusiera que hasta que la CMT no diera cumplimiento a dicho mecanismo secuencial — momento que, por lo demás, trazaba la frontera concreta para la aplicación efectiva del nuevo régimen del REMERCADOS - seguirían en vigor las obligaciones impuestas conforme al régimen de la anterior LGTel de 1998 a los «operadores dominantes» —expresión en cierto sentido antecedente de la actual de operadores con poder significativo-, así como las disposiciones y acuerdos de la Comisión Delegada del Gobierno para Asuntos Económicos en materia de regulación y fijación de precios de los servicios de telecomunicaciones. Todo ello sin perjuicio de la aplicación también, con carácter transitorio, de algunas reglas específicas en materia de presentación de contabilidad de costes por los operadores (reglas recogidas en la disp. transitoria $7^{\mathrm{a}}$ LGTEL).
} 
son propias del régimen general, y por tanto ajenas a la excepción a dicho régimen general que viene a constituir el servicio universal).

La complejidad ya comentada del proceso de fijación y análisis de los mercados de referencia y el que ello operara como condición para esa desregulación de los precios ha hecho que hasta hace poco el régimen efectivo de los precios estuviera presidido aún por una cierta indefinición transitoria ${ }^{7}$ y la discrecionalidad gubernamental, sobre todo en lo que respecta a Telefónica, dada su doble condición de operador generalmente dominante y de operador legalmente designado por plazo transitorio para la prestación del servicio universal. Pero una vez fijados y analizados por la CMT los correspondientes mercados de referencia, como recientemente ha tenido lugar, puede decirse hemos entrado en el definitivo sistema de precios del régimen general previstos por la LGTEL, libres, salvo en lo que la CMT establezca para los operadores con poder significativo en cada uno de dichos mercados (por ejemplo, Telefónica, en lo que respecta a los precios de la conexión y el abono en el servicio de telefonía fija).

\section{Los regímenes específicos}

Pero junto al régimen general de las telecomunicaciones que acabamos de sintetizar, y contraponiéndolo a éste dispone la LGTEL: «Sólo tienen la consideración de servicio público o están sometidos a obligaciones de servicio público los servicios regulados en el artículo 4 y en el Título III de esta Ley» (art. $\left.2^{\circ} .2\right)$.

De esta manera la Ley superpone a las actividades del régimen general (actividades libres y desarrolladas en libre competencia, aunque sujetas, bajo su calificación como «servicios de interés general», a la mera regulación de «policía administrativa» que viene a ser la actual «regulación económica»), de un lado, las que reconduce a ciertos efectos al «servicio público» en el sentido clásico o estricto de este concepto (los supuestos de su artículo 4) y, de otro, como nivel intermedio, aquéllas a las que, aun siendo de titularidad

\footnotetext{
${ }^{7}$ Conforme a las previsiones transitorias de la LGTEL (disp. transitoria $1^{\mathrm{a}}$ ), hasta que la CMT no fijara los mercados de referencia, identificara en su caso los operadores con poder significativo e impusiera a estos las correspondientes obligaciones específicas, seguirían en vigor la normativa y los acuerdos de la Comisión Delegada del Gobierno sobre Asuntos Económicos en vigor en materia de regulación y fijación de precios, aunque la Comisión Delegada —durante dicho plazo — podría fijar transitoriamente, modificando, pues, sus acuerdos anteriores, precios fijos, máximos y mínimos o los criterios para su fijación y los mecanismos para su control, en función de los costes reales de la prestación del servicio y del grado de concurrencia de operadores en el mercado, de forma tal que se garantice la concurrencia, el control de las situaciones de abuso de posición dominante y el acceso a los servicios a preciso asequible (disp. transitoria $3^{\mathrm{a}}$ LGTEL). A diferencia de la similar previsión de la disp. transitoria $4^{\mathrm{a}}$ de la LGTel de 1998, que lo hacía «sine die», la vigente LGTEL sólo contempla, pues, esa regulación de los precios por la Comisión Delegada del Gobierno para Asuntos Económicos durante un plazo de transición que tiene como término final la fijación por la CMT de los mercados de referencia y determinación de los operadores con poder significativo y sus obligaciones específicas.
} 
y gestión privada, se les impongan las llamadas «obligaciones de servicio público».

\subsection{Actividades configuradas como servicio público en sentido clásico}

Como hemos visto, el artículo $2^{\circ} .2$ LGTEL dice que tienen la consideración de «servicio público» los servicios a que se refiere su artículo $4^{\circ}$. Pero este artículo recoge dos distintos supuestos. De un lado, las redes y servicios de telecomunicaciones que desarrollen actividades esenciales para la defensa nacional, y que como «se reservan al Estado y se rigen por su normativa específica» (art. $4^{\circ} .1$ ), quedan por tanto atribuídos en exclusiva al Estado para su desarrollo - en los términos que prevea esa normativa específica- conforme a la claves y régimen del servicio público en el sentido estricto o clásico de este concepto.

Pero, de otro lado, la LGTEL (art. $4^{\circ} .5$ ) contempla (no obstante la liberalización y la libre competencia que, salvo la excepción que acabamos de mencionar, preside el régimen general de las telecomunicaciones) que con carácter excepcional y transitorio, el Gobierno podrá de oficio o a instancia de cualquier Administración territorial, acordar la asunción por la Administración del Estado de la gestión directa de determinados servicios o la explotación de ciertas redes «para garantizar la seguridad pública o la defensa nacional» o en el caso de incumplimiento de las obligaciones de servicio público por parte de los operadores (hay que entender, para asegurar los fines que tales obligaciones instrumentan), a lo que añade la posibilidad de la intervención estatal de los servicios que vengan prestando los operadores de telecomunicaciones en ese mismo caso de incumplimiento de sus obligaciones de servicio público.

Conviene hacer en relación con estos últimos supuestos del art. $4^{\circ}$ LGTEL estas precisiones. No hay en ellos una «publicatio» estricta (reserva al Estado, al sector público) de dichas actividades, sino tan sólo esa posibilidad de la intervención estatal de unas redes o servicios determinados o de la asunción por el Estado - siempre excepcional y transitoria- de la mera gestión (no de la titularidad), en todo caso directa, también de unas redes o servicios determinados. Estas previsiones - ya recogidas en la LGTel de 1998- son así bien descriptivas de la neorregulación: el que la garantía del adecuado funcionamiento de las telecomunicaciones no requiere su «publicatio» estricta (su reserva general al sector público); basta con que, establecido ya el principio de su titularidad privada y su desarrollo en libre competencia, el Estado tenga la posibilidad de imponer las condiciones de su prestación (que hemos visto en el régimen general), en su caso las obligaciones de servicio público (a que luego nos referiremos), e incluso en último extremo y ante las circunstancias comentadas, la de asumir — con ese carácter excepcional y transitorio- o intervenir su gestión. 
Y aunque la LGTEL dice que tales actuaciones del Estado (asunción excepcional y transitoria de la gestión directa; intervención) se efectuarán «de acuerdo con la LCAP», no cabe deducir de esta remisión «publificación» alguna, pues su función es tan sólo la de integrar el régimen de dichos supuestos con la aplicación de la LCAP en lo que proceda (repárese que no hay aquí contrato de la Administración). ¿Y en qué procederá? Entiendo que en aquellas de sus previsiones en que quepa subsumir los citados supuestos (asunción «ex post» y excepcional de la gestión directa; intervención del servicio), por ejemplo y respectivamente, el rescate del servicio por la Administración (art. 167.b y 168.2 LCAP) y la intervención del mismo (art. 166 LCAP) (aunque ciertamente queden algunas cuestiones en el aire; por ejemplo, si en el caso de la asunción de la gestión directa, y por aplicación del régimen del rescate — art. 169.4 LCAP-, la Administración deberá indemnizar al titular del servicio por los daños que se le irroguen, cuestión esta en la que no podemos detenernos).

Aclaremos, en fin, que la iniciativa de las Administraciones territoriales para que el Gobierno de la Nación adopte la decisión de asumir la gestión directa o la intervención de las correspondientes redes y servicios de telecomunicaciones sólo podrá tener lugar si esa Administración territorial tiene competencias en materia de seguridad o para la prestación de los servicios públicos afectados por el anormal funcionamiento del servicio o de la red de comunicaciones electrónicas (art. $4^{\circ} .5$ LGTEL). Es decir, para garantizar la seguridad pública o los servicios públicos —en este caso, funciones o servicios de la competencia de esa Administración territorial- que pudieran verse perturbados por el mal desarrollo de las redes y servicios de telecomunicaciones por parte de los operadores privados.

\subsection{El servicio universal como primera categoría de las obligaciones de servicio público}

La LGTEL dedica el capítulo I de su Título III a las llamadas «obligaciones de servicio público», institución —-traída del Derecho comunitario-mediante la que trata de garantizar la existencia de servicios de telecomunicaciones de calidad adecuada en todo el territorio nacional. Esa garantía pasaba en el tradicional régimen de las prestaciones al público por la publificación de tales servicios (su conversión en servicio público en el sentido clásico). Pero ahora, en la neorregulación, ese objetivo no requiere ya esa asunción en exclusiva de la titularidad de los servicios por el sector público, sino que, desarrollados éstos por el sector privado y en libre competencia, basta con que los operadores privados queden sujetos, en su caso, a una serie de obligaciones que con contenido funcional u objetivo de servicio público vienen a cubrir así los objetivos que antes cumplía el viejo servicio público de titularidad administrativa. En suma, las «obligaciones de servicio público» responden a 
los mismos ejes finalistas que la regulación general de las telecomunicaciones (conjugar la libre prestación de los servicios en competencia y en el mercado, con la garantía de su disfrute por los usuarios y de los derechos de éstos), sólo que con un grado más intenso de intervención pública regulatoria. Nivel más intenso que la Ley evoca como connotación de fondo de las obligaciones de servicio público: solventar aquellas circunstancias en que «las necesidades de los usuarios finales no se vean atendidas de manera satisfactoria por el -mero- mercado» (art. 20.1).

La LGTEL incluye, no obstante, dentro de la noción de «obligaciones de servicio público» dos categorías institucionalmente bien diferenciadas. De un lado, el llamado «servicio universal» y, de otro, las «otras obligaciones de servicio público». Pues bien, se entiende por servicio universal de telecomunicaciones - primera categoría que vamos a analizar- «el conjunto definido de servicios cuya prestación se garantiza para todos los usuarios finales con independencia de su localización geográfica, con una calidad determinada y a precio asequible» (art. 22.1 LGTEL).

\section{a) Prestaciones que integra}

Bajo el concepto de servicio universal, en los términos fijados por la LGTEL y el RESERVICIOS, (arts. 27-34), ha de garantizarse:

a) Que todos los usuarios finales puedan obtener una conexión a la red telefónica pública desde una instalación fija y acceder al servicio telefónico disponible al público, siempre que sus solicitudes se consideren razonables en los términos que reglamentariamente se determinen. La conexión debe ofrecer al usuario final la posibilidad de efectuar y recibir llamadas telefónicas y permitir comunicaciones de fax y datos a velocidad suficiente para acceder de forma funcional a Internet ${ }^{8}$.

b) Que se ponga a disposición de los abonados al servicio telefónico disponible al público una guía general de números de abonados, impresa o electrónica, o ambas, a actualizar al menos una vez al año. Asimismo que se ponga a disposición de todos los usuarios finales de dicho servicio, incluídos

\footnotetext{
${ }^{8}$ Según el RESERVICIOS se considera «velocidad suficiente» la que se utiliza generalmente para acceder a Internet por los abonados al servicio telefónico fijo mediante pares de cobre y modem para banda vocal. Y se consideran «razonables» las solicitudes de conexión en las que se den alguna de estas condiciones: a) que la conexión se solicite para cualquier inmueble situado en suelo urbano; b) para una edificación de las previstas en la disposición transitoria $5^{a}, 1$ del Texto Refundido de la Ley del Suelo de 1992 (es decir, en suelo urbanizable, pero ya existentes y realizadas de conformidad con la ordenación urbanística aplicable o respecto de la que ya no proceda dictar medidas de restablecimiento de la legalidad urbanística que impliquen su demolición), siempre que dicha edificación esté destinada a uso residencial como vivienda habitual del solicitante; c) para una edificación destinada a uso residencial como vivienda habitual del solicitante que, aunque esté en suelo no urbanizable, haya sido excepcionalmente autorizada de acuerdo con lo dispuesto en el artículo 20.1, párrafo segundo de la LRSV de 1998.
} 
los usuarios de teléfonos públicos de pago, al menos un servicio de información general (de «consulta telefónica», precisa el RESERVICIOS) sobre números de abonados. Todos los abonados al servicio telefónico disponible al público tendrán derecho a figurar en la mencionada guía general, sin perjuicio en todo caso del respeto de las normas que regulen la protección de los datos personales y el derecho a la intimidad ${ }^{9}$.

c) Que exista una oferta suficiente de teléfonos públicos de pago, en todo el territorio nacional, que satisfaga razonablemente las necesidades de los usuarios finales, en cobertura geográfica, números de aparatos, accesibilidad de estos teléfonos para los usuarios discapacitados y calidad de los servicios, y con la posibilidad de efectuar gratuitamente llamadas de emergencia desde dichos teléfonos públicos de pago sin tener que utilizar ninguna forma de pago, utilizando el número único de llamadas de emergencia 112 y otros números de emergencia ${ }^{10}$.

d) Que los usuarios finales con discapacidades tengan acceso al servicio telefónico disponible al público desde una ubicación fija y a los demás elementos del servicio universal en condiciones equiparables a las que se ofrecen al resto de usuarios finales (el RESERVICIOS — art. 33 - precisa las condiciones para facilitar dicha accesibilidad).

e) Que cuando así se establezca reglamentariamente, se ofrezca a los consumidores que sean personas físicas, opciones o paquetes de tarifas que difieran de las aplicadas en condiciones normales de explotación comercial con objeto de garantizar, en particular, a las personas con necesidades sociales especiales la posibilidad de tener acceso al servicio telefónico disponible al público o hacer uso de éste. El RESERVICIOS ha concretado esta previsión

\footnotetext{
${ }^{9}$ Según dispone el RESERVICIOS, cuando la elaboración de la guía no quede garantizada por el libre mercado, su elaboración corresponderá al operador que tenga encomendada la prestación del servicio universal, el cual habrá de entregarla gratuitamente a sus abonados y ponerla gratuitamente a disposición tanto del resto de abonados al servicio telefónico disponible al público como de los demás operadores que presten dicho servicio. Por otra parte, dicho operador encargado del servicio universal pondrá a disposición de todos los usuarios finales del servicio telefónico disponible al público un servicio de consulta telefónica sobre números de abonados contenidos en las guías telefónicas, actualizado y de ámbito nacional (este servicio se prestará a precio asequible, pero tendrá carácter gratuito para el usuario cuando se efectúe desde un teléfono público de pago).

${ }^{10}$ Conforme al RESERVICIOS (art. 32) se considerarán teléfonos públicos de pago los situados en el dominio público de uso común, debiendo el operador designado para prestar el servicio universal garantizar la existencia de una oferta suficiente de dichos teléfonos en la zona correspondiente a su designación. Se considera oferta suficiente la existencia de al menos 1 teléfono público de pago y 1 más por cada 1.500 habitantes en cada municipio de 500 o más habitantes, y de 1 teléfono público de pago en cada uno de los municipios de menos de 500 habitantes en los que esté justificado sobre la base de la existencia de una distancia elevada a facilidades similares, la baja penetración del teléfono fijo, la falta de accesibilidad del servicio telefónico móvil o la elevada tasa de población flotante. El operador designado debe satisfacer en plazo razonable todas las solicitudes de nuevos teléfonos públicos de pago que le presenten los Ayuntamientos hasta cumplir con la «oferta suficiente» bajo supervisión del Ministerio de Industria, que resolverá los conflictos (en todo caso, hasta el 31 de diciembre de 2007 los teléfonos públicos de servicio instalados en las dependencias municipales serán tenidos en cuenta a efectos de esa «oferta suficiente»).
} 
tan sólo para las personas con necesidades sociales especiales (art. 27.2.e) estableciendo el oportuno régimen en el contexto de su regulación de la asequibilidad de los precios del servicio universal (art. 35 y ss.) según veremos.

f) Que se apliquen, cuando proceda, opciones tarifarias especiales o limitaciones de precios, tarifas comunes, equiparación geográfica u otros regímenes similares, de acuerdo con condiciones transparentes, públicas y no discriminatorias.

g) Por lo demás, teniendo en cuenta que la «calidad determinada» de los servicios garantizados es, junto a la asequibilidad de su precio, elemento integrante del servicio universal, el RESERVICIOS precisa las condiciones relativas a la calidad de las prestaciones (art. 34) a concretar por Orden ministerial.

Hasta aquí el contenido sustantivo, legalmente definido, del servicio universal. Como puede apreciarse, al cabo, la conexión a la red telefónica fija disponible al público y el acceso al servicio telefónico fijo disponible al público en los términos expuestos (si bien el Gobierno, de conformidad con la normativa comunitaria, podrá revisar el alcance de las obligaciones del servicio universal) (art. 22. 4 LGTEL). De esta manera, en gran medida el servicio universal viene a recoger el contenido objetivo del viejo servicio público de titularidad administrativa (gestionado en concesión y sujeto a la reglamentación del servicio y a tarifas), pero concebida ahora su prestación, ya no como tarea de la Administración, sino de los operadores privados y para ser prestado en el mercado conforme a precios asequibles. De ahí que los principales rasgos de definición distintivos del servicio universal frente al viejo servicio publico radiquen en la determinación de los operadores obligados a su prestación, la asequibilidad de los precios del servicio, y su financiación.

\section{b) Operadores encargados de su prestación}

Sin perjuicio de la designación «ex lege» — por la propia LGTEL— de Telefónica como operador encargado en régimen transitorio de la prestación del servicio universal (cuestión a la que luego nos referiremos), la LGTEL dispone que la Administración del Estado (Ministerio de Industria) podrá designar uno o más operadores para garantizar la prestación del servicio universal, de manera que quede cubierta la totalidad del territorio nacional, y pudiendo designarse operadores diferentes para la prestación de diversos elementos del servicio universal y abarcar distintas zonas del territorio nacional.

El sistema para tal designación, una de las novedades de la LGTEL respecto de la LGTel de 1998, y que aquella remite a su concreción por Real Decreto (como en efecto se ha hecho mediante el RESERVICIOS), ha de incluir un mecanismo de licitación pública para todos o algunos de los servicios y prestaciones que integran el servicio universal, a aplicar cuando de un proceso de consulta pública resulte que varios operadores están interesa- 
dos en ser designados para una zona geográfica determinada con carácter exclusivo o en competencia con otros operadores, y que será preferente sobre el de designación directa ${ }^{11}$.

\section{c) La asequibilidad de los precios}

El carácter asequible de sus precios es una connotación definidora del servicio universal de telecomunicaciones. Esta asequibilidad es objeto, no obstante, en la LGTEL de tan sólo esta definición genérica: «que en los términos y condiciones que reglamentariamente se determinen por el Gobierno, se apliquen, cuando proceda, opciones tarifarias especiales o limitaciones de precios, tarifas comunes, equiparación geográfica u otros regímenes similares, de acuerdo con condiciones transparentes, públicas y no discriminatorias» (art. 22.1.f) y «que cuando así se establezca reglamentariamente, se ofrezcan a los consumidores que sean personas físicas, de acuerdo con condiciones transparentes, públicas y no discriminatorias, opciones o paquetes de tarifas que difieran de las apli-

${ }^{11}$ El régimen de estos dos posibles mecanismos de designación de los operadores encargados del servicio universal ha sido detallado por el RESERVICIOS (arts. 37 y 38) conforme a esta secuencia:

a) El Ministerio de Industria — con dos años de antelación a la finalización del plazo establecido para la prestación del servicio universal en una determinada zona - realizará una consulta pública para determinar si, en los ámbitos territoriales que en ella se establezcan, existen operadores interesados en prestarlo y en qué condiciones.

b) En las zonas en que algún operador haya comunicado al Ministerio su intención de prestarlo, se tramitará un procedimiento de licitación pública (salvo que el único operador que así lo manifieste sea el que ya estaba designado en el momento de la consulta, en cuyo caso el Ministerio podrá optar entre proceder a la licitación o su designación directa).

c) Mediante Orden Ministerial, previo informe de la CMT, se convocará el correspondiente concurso (la convocatoria incluirá el servicio o elemento a prestar, el ámbito territorial, el período y las condiciones de prestación y de financiación).

d) Podrán presentarse al concurso, con carácter vinculante los operadores que en la consulta pública hubieran comunicado su intención de prestar el servicio universal en la correspondiente zona, y en general «cualquier empresa legalmente establecida y debidamente autorizada para la prestación del elemento del servicio universal al que se refiera el concurso» (art.37.3 RESERVICIOS).

e) El Ministerio de Industria adjudicará el concurso al licitador que ofrezca las condiciones más ventajosas. La empresa adjudicataria tendrá la consideración de operador designado para la prestación del servicio universal y consecuentemente se beneficiará del peculiar régimen de financiación del servicio universal en cuanto al correspondiente elemento de éste y a la zona objeto de la adjudicación.

f) Si tras la citada consulta pública inicial ningún operador manifestara su interés en prestar el servicio universal, o si el concurso se declarara desierto, se procederá mediante Orden Ministerial, previo informe de la CMT, a la designación directa del operador encargado de prestarlo.

En principio, cualquier operador con poder significativo en el mercado de suministro de la conexión a la red telefónica pública y su utilización desde una ubicación fija en una zona determinada, o que se encuentre prestando el servicio universal, podrá ser designado directamente para prestar, dentro de ella, cualesquiera de los elementos incluídos en el servicio universal. Pero si en una zona determinada no existieran operadores con dicho poder significativo, se podrá designar, previa consulta a las partes implicadas, a cualquiera de los operadores con mayor cuota de participación en dicho mercado. La Orden Ministerial establecerá el servicio o elemento a prestar, el ámbito territorial, el período y las condiciones de prestación del servicio (art. 38 RESERVICIOS, que en este caso, y frente a lo expresamente recogido en el caso de la designación mediante licitación, no se refiere a la financiación). 
cadas en condiciones normales de explotación comercial, con objeto de garantizar, en particular, que las personas con necesidades sociales especiales tengan acceso al servicio telefónico disponible al público o hacer uso de éste» (art. 22.1.e).

La cuestión queda, pues, básicamente remitida al reglamento. Eso sí, desde la previsión legal de que (frente a lo que sucede en el régimen general de los servicios de telecomunicaciones, presidido, según vimos, por la libertad de precios en libre competencia, aunque con la posibilidad de que la CMT pueda imponer a los operadores con poder significativo medidas de control de precios, los cuales, aun así, serán «comerciales») al operador encargado del servicio universal se le puede imponer que, en atención a esas circunstancias del art. 22.1 e y f LGTEL, aplique un régimen de precios que en los términos citados (precios limitados, opciones tarifarias especiales, etc.) difieran de los aplicables en condiciones de mera explotación comercial.

Y, en efecto, el RESERVICIOS ha concretado (art. 35) esa previsión legal definiendo la asequibilidad para los usuarios de los precios del servicio universal por el cumplimiento por éstos de determinados objetivos: que los precios en las zonas de alto coste, rurales, insulares y distantes sean comparables con los de las áreas urbanas; que exista una oferta suficiente a precio uniforme de teléfonos de uso público en el dominio público común, en todo el territorio nacional; que se ofrezcan planes de precios que no limiten la posibilidad de ser usuario del servicio, y consecuentemente, el operador designado para prestar el servicio universal debe ofrecer a sus abonados: programas de precios que permitan a éstos el máximo control del gasto, y en particular programas de abono social, para jubilados y pensionistas (con bonificación de precios), programas para invidentes o usuarios con graves dificultades visuales (franquicias en consulta telefónica, etc.), para sordos o con graves dificultades auditivas (programas de precios para teléfonos de texto); la posibilidad de que el usuario elija la frecuencia de facturación de su preferencia; de restringir y bloquear las llamadas internacionales y las que se hagan a servicios de tarificación adicional; un nivel básico y gratuito de detalle en la facturación que permita al usuario el seguimiento de su gasto; medios para el abono previo o el pago de manera escalonada, etc.

En definitiva, y como puede advertirse, un acotamiento abstracto e indirecto de la asequibilidad de los precios que, a última hora, tiene su mecanismo de concreción más definido en la previsión de que la Comisión Delegada del Gobierno para Asuntos Económicos «garantizará el carácter asequible» de los precios del servicio universal, en especial, en el caso de los colectivos de pensionistas y jubilados de renta familiar baja y de personas discapacitadas (art. 33.1 RESERVICIOS). Sobre todo si pensamos que, pese a que expresamente no se reconoce a dicha Comisión la facultad de fijar los precios, en esa función «de garantía» de la asequibilidad podrían integrarse modalidades diversas de control de aquellos, incluida, en su caso, su fijación o el establecimiento de límites a los mismos. 
LA REGULACIÓN DE LAS TELECOMUNICACIONES Y LA ADMINISTRACIÓN LOCAL

\section{d) Su financiación}

Una característica de las «obligaciones de servicio público» en el Derecho comunitario - y el servicio universal es una, la fundamental categoría de ellas - es que, siendo las mismas un «plus» o carga impuesta a los operadores, y añadida al desarrollo por éstos de la prestación de los servicios en régimen general comercial, por lo que en tal caso dicha prestación puede resultarles no rentable, es que el coste de tales obligaciones no puede ser a cargo del operador encargado de su cumplimiento, sino que ha de serle financiado externamente. Pues bien, a tal fin y en lo que respecta al servicio universal la LGTEL y el RESERVICIOS establecen el siguiente sistema.

$\left.1^{\circ}\right)$ La CMT ha de determinar si la prestación del servicio universal supone para el operador designado para prestarlo un «coste neto» - conforme a los mecanismos de determinación y cálculo de ese coste neto que recoge el RESERVICIOS - y por tanto una carga injustificada. Ello irá de suyo en el caso de la designación mediante licitación pública (ya hemos dicho que si el operador es designado mediante concurso adquiere «ex lege» la condición de beneficiario de la financiación del servicio universal), pero no en el caso de designación directa, en el que la existencia de dicha carga injustificada ha de ser determinada anualmente por la CMT, por resolución motivada (de manera que la CMT puede resolver que no hay tal carga injustificada y el operador no tener derecho a la financiación del servicio universal que presta).

$2^{\circ}$ El coste neto, como carga injustificada, será financiado por un mecanismo que alternativamente puede ser, de reparto de dicho coste entre los operadores a través del Fondo Nacional del Servicio Universal, o de compensación directa entre operadores. En el primer caso la CMT ha de determinar las aportaciones que corresponden a cada operador con obligación de contribuir al Fondo y que se ingresarán en éste, el cual por su parte abonará el coste neto al operador del servicio universal. El segundo mecanismo, de compensación directa entre operadores, es contemplado por la Ley como de carácter marginal («cuando la magnitud del coste no justifique los costes de gestión del Fondo») (art. 24.4), es más, como alternativo a la propia existencia del Fondo, por quedar establecido en el RESERVICIOS (art. 50.1) — como anteriormente bajo el régimen de la LGTel de 1998- que en tal supuesto de escasa magnitud del coste del servicio universal y puesta en práctica de este mecanismo de compensación directa, dicho Fondo será suprimido.

Como puede apreciarse, la regulación de la financiación del servicio universal, a partir de esta segunda hipótesis, propicia la conjetura de que la misma no pase de una previsión «testimonial» y de la que el legislador estaría bien dispuesto a prescindir (y, en efecto, así lo es institucionalmente: el servicio universal, y su financiación, sólo es una garantía para el caso de que el mercado «per se» no satisfaga las correspondientes solicitudes de prestación y 
a precio asequible). Y de hecho, bajo la LGTel de 1998, que ya la regulaba, ni la financiación ni el Fondo del servicio universal llegaron a ponerse en práctica. Sin duda porque siendo Telefónica la operadora encargada de su prestación - y al tiempo operadora dominante - la CMT resolvió que su prestación no suponía para esta compañía una desventaja competitiva que justifican una compensación financiera.

En todo caso hoy, ya bajo la LGTEL de 2003 y el RESERVICIOS, con 2007 - según vamos a ver- como término a plazo de la responsabilidad de Telefónica como operador del servicio universal, y dado ese mecanismo pautado que ha de llevar a la preferente licitación pública para la designación del operador u operadores del servicio universal, parece que sólo la puesta en práctica de la financiación de éste y del correspondiente Fondo podrían en el futuro garantizar esa concurrencia para ser designado operador responsable a tal fin y con ello que el servicio universal cumpliera sus objetivos (universalidad geográfica, calidad, precio asequible); y, es más, que sobre esa base pueda tener lugar la expansión de las redes y servicios por parte de diversos operadores concurrentes en el conjunto del sector. Porque la universalidad geográfica exigirá una inversión en infraestructura que el operador responsable del servicio universal no cubrirá si no es con la consiguiente compensación financiera (inversión que, por lo demás, aquél o el operador con poder significativo en el mercado rehuirán, una vez que en un régimen de precios libres no puedan ya disponer del lenitivo que bajo precios regulados suponía la modulación por la Administración en su favor de los diversos componentes de la «cesta de precios» regulados). Porque la calidad se resentirá en la medida que el operador del servicio universal, si no recibe la compensación de su coste neto, tratará de ajustarla al mínimo coste. Y porque también lo hará la asequibilidad de los precios, pues sin financiación externa el operador responsable del servicio universal tratará de repercutir su coste neto en los precios de éste o en otros servicios que preste.

\section{e) Régimen transitorio}

El servicio universal de telecomunicaciones estaba ya regulado por la LGTel de 1998 (y el anterior Reglamento del Servicio Universal, dictado para su desarrollo). De ahí las previsiones transitorias de la actual LGTEL de 2003: la vigencia de la normativa sustantiva anterior sobre el servicio universal hasta que no se aprobara, en desarrollo de esta última, la nueva reglamentación sobre el servicio universal, la cual debería en especial regular la transición al nuevo sistema de designación del operador encargado de su prestación (disposición transitoria $1^{\mathrm{a}}$. 5 LGTEL). Y es que, en efecto, por otra parte y en paralelo, la LGTEL (disposición transitoria $2^{\mathrm{a}}$ ) establece que la prestación del servicio universal continuaría correspondiendo a Telefónica de España, SAU, durante ese mismo período transitorio, es decir, hasta la fecha en que esa nueva 
reglamentación fuera aprobada, momento en que en que se estaría al respecto a lo dispuesto en él ${ }^{12}$.

Pues bien, publicado esa nueva reglamentación —el RESERVICIOS de 2005- éste, por una parte, ha prolongado la obligación de Telefónica de prestar el servicio universal hasta el 31 de diciembre de 2007. Lo que deberá hacer conforme a la nueva regulación sustantiva del servicio universal, aunque con algunas modulaciones recogidas en la disposición transitoria $2^{\mathrm{a}}$ del RESERVICIOS (modificación de la oferta de los teléfonos públicos de pago a petición de los Ayuntamientos, y mantenimiento de la consideración como tales a efectos de su «oferta suficiente» de los teléfonos públicos de servicio instalados en dependencias municipales).

Por otra parte, además, ha establecido el mecanismo de transición hacia el sistema definitivo de designación de los operadores encargados del servicio universal en estos términos: 1) Realización por el Ministerio de Industria, con fecha límite del 31 de diciembre de 2005, de la consulta pública inicial para la designación del operador encargado del servicio universal, consulta prevista con carácter general en el art. 37 RESERVICIOS. 2) A la vista de los resultados de dicha consulta y en todo caso antes del 31 de diciembre de 2006, el Ministerio de Industria debe proceder (hay que entender, conforme al régimen general: licitación o designación directa subsidiaria) a la designación del operador u operadores encargados del servicio universal, por ámbitos territoriales, sus diversos elementos y plazos si procede. 3) Resolución por el Ministerio de Industria del tránsito ordenado del cese de las obligaciones de servicio universal de Telefónica a la asunción de éste por los nuevos operadores designados.

\subsection{Las llamadas otras obligaciones de servicio público}

Como segunda categoría dentro de las obligaciones de servicio público, el art. 25 LGTEL regula las «otras obligaciones de servicio público» distintas de la del servicio universal, que a su vez clasifica en estos grupos:

a) Las que el Gobierno podrá imponer, estableciendo sus condiciones, por razones de defensa nacional, seguridad pública, seguridad de las personas o la protección civil.

b) Las que el Gobierno asimismo podrá imponer por razones de cohesión territorial, extensión del uso de nuevos servicios y tecnologías (en es-

\footnotetext{
${ }^{12}$ La LGTel de 1998 dispuso la designación «ex lege» de Telefónica, en tanto que operador dominante, como operador del servicio universal, previendo, no obstante, que en todo caso a lo largo de 2005 la CMT determinaría si a partir del 1 de enero de 2006 Telefónica conservaría o no, en cada ámbito territorial, esa condición. Pero antes de que esta última fecha se cumpliera, se aprobó la nueva LGTEL de 2003, la cual moduló ese plazo durante el que Telefónica seguiría manteniendo tal condición con un nuevo término final: como hemos dicho, la fecha de aprobación de la nueva reglamentación del servicio universal, momento en que a ese respecto habría que estar a lo que éste dispusiera.
} 
pecial, a la sanidad, la educación, la acción social y la cultura), facilitar la comunicación entre determinados colectivos que se encuentren en circunstancias especiales, o la disponibilidad de servicios que comporten la acreditación de fehaciencia del contenido del mensaje remitido o de su remisión o recepción ${ }^{13}$.

c) La obligación de encaminar las llamadas a los servicios de emergencia al número 112 y otros que se determinen mediante Real Decreto, incluídas las que se efectúen desde teléfonos públicos de pago, que incumbe a los operadores con carácter gratuito para los usuarios.

d) Determinadas obligaciones de los operadores de redes utilizadas para la prestación de los servicios de radio y televisión, o como las denomina el RESERVICIOS, «obligaciones de servicio público en materia de transmisión de determinados canales y servicios de programas de radiodifusión y televisión» $\left(\right.$ art. 56) ${ }^{14}$.

\section{Derechos y obligaciones de los operadores y usuarios y su garantía}

La regulación general de las telecomunicaciones abarca, en fin, como es lógico, un estatuto definido de derechos y obligaciones de los diversos agentes

\footnotetext{
${ }^{13}$ Estos servicios, ahora configurados como «obligaciones de servicio público», eran calificados por la LGTel de 1998 como «servicios obligatorios» — categoría suprimida por la LGTEL de 2003- y algunos de ellos fueron encomendados por aquélla transitoriamente a Correos y Telégrafos (servicios de télex, telégrafos y similares) y a la Dirección General de la Marina Mercante (servicios para la seguridad de la vida humana en el mar). Una encomienda ésta que la vigente LGTEL (disposición transitoria $\left.4^{\mathrm{a}}\right)$ prolongó transitoriamente hasta que no se desarrollara reglamentariamente el régimen de esta categoría de «otras obligaciones de servicio público».
}

Pues bien, el RESERVICIOS (que regula en su art. 55 el régimen de las «otras obligaciones de servicio público») sigue atribuyendo a la Dirección General de la Marina mercante, por plazo de 4 años, el servicio de seguridad de la vida humana en el mar, y a Correos y Telégrafos los citados servicios que comporten la acreditación fehaciente del contenido del mensaje o de su remisión o recepción, todo ello hasta que por Orden del Ministerio de la Presidencia se regulen las características técnicas de tales servicios.

${ }^{14}$ En concreto: $1^{\circ}$ ) Al operador con poder significativo en el mercado de los servicios soporte de los de televisión se le podrán imponer como obligaciones de servicio público (de no serlo como obligaciones específicas de su condición de operador con poder significativo) prestar dicho servicio portador (hasta ese momento y con carácter transitorio lo prestará, como obligación de servicio público, Retevisión SA, tal y como determinó la O.M. de 9 de marzo de 2001 que aprobó el Reglamento del dominio público radioeléctrico). $2^{\circ}$ ) Los operadores de redes estarán obligados a cumplir las exigencias de transmisión de determinados canales y servicios de programas de radio y televisión, así como las que sobre cobertura y calidad se establezcan. Todo ello sin perjuicio de que hasta ese momento y con carácter transitorio ex LGTEL (disposición transitoria $6^{\mathrm{a}}$.1) haya que estar a las normas vigente sobre acceso a la radio y la televisión digital en general y mediante acceso condicional, y sobre la televisión de formato ancho: en concreto, a lo previsto por la Ley 17/1997, sobre el uso de normas para la transmisión de señales de televisión, y por la Ley de Telecomunicaciones por Cable de 1995 sobre la distribución por la televisión por cable de los programas de la televisión analógica estatal y autonómica (ya nos hemos referido a que la Ley de la comunicación audiovisual de Cataluña recoge similares obligaciones para los operadores de redes). 
concernidos (operadores y usuarios) que la LGTEL acota en los siguientes términos:

\subsection{La posición jurídica de los operadores y los derechos de los usuarios}

En el estatuto jurídico de los operadores se integran los derechos y obligaciones de carácter general que el RESERVICIOS (arts. 15 y ss.) sistematiza como condiciones para el desarrollo de las actividades de telecomunicación en régimen general a que ya nos hemos referido, incluída la de suministro de información a las Autoridades Nacionales de reglamentación; los derechos de ocupación del dominio público y la propiedad privada a que luego nos referiremos; y las obligaciones relativas al secreto de las comunicaciones y la protección de los datos personales.

En cuanto a los derechos de los usuarios la LGTEL los regula con carácter general (por tanto, tenga o no impuestas el operador «obligaciones de servicio público») (artículo 38) y no excluyente de la aplicación asimismo de lo previsto en la legislación general de protección de los consumidores y usuarios. Lo hace en todo caso desde un planteamiento y técnica peculiares. Para empezar, distingue entre lo que podríamos calificar de derechos generales de los consumidores y otros usuarios finales de los servicios de telecomunicaciones (art. 38.2) y los que en particular corresponden a los abonados a estos servicios (art. 38.3), todos estos últimos derechos relativos a la protección de los datos personales. Y remite además el contenido de los primeros (que enuncia más o menos en abstracto) a su concreción reglamentaria, añadiéndose a lo aleatorio de esta técnica normativa el que en ese repertorio legal no se incluyen los derechos típicos propios del régimen de las obligaciones de servicio público y del servicio universal (probablemente porque en algún caso van de suyo o se recogen en otros apartados de la Ley, son subsumibles en dicho repertorio, o bien por pura omisión).

Se hacía, pues, necesaria la sistematización reglamentaria de estos derechos, cosa que en efecto ha hecho el RESERVICIOS (art. 103 y ss.) predicándolos, ciertamente desde la perspectiva neorregulatoria, con carácter general de los «consumidores» y no específicamente de los usuarios de un servicio público (como era convencional en el viejo régimen de éste) ${ }^{15}$.

15 En esa sistematización se incluyen los siguientes derechos:

A) De carácter general:

a) A la responsabilidad por los daños que se les produzcan, que se exigirá conforme a lo previsto en la legislación civil o la sectorial que resulte de aplicación.

b) A la información veraz, eficaz, suficiente, transparente y actualizada (el operador deberá poner a disposición pública la información que señala el art. 38. 2 RESERVICIOS).

c) A que se respeten en plazo las ofertas publicitarias.

d) A la desconexión en plazo de 10 días, previa solicitud, del servicio telefónico disponible al público. 


\subsection{Resolución de conflictos entre operadores y usuarios}

Dispone la LGTEL que los operadores de telecomunicaciones y los usuarios finales podrán someter a las Juntas Arbitrales de Consumo las controversias que les enfrenten de acuerdo con la legislación sobre la defensa de los consumidores y usuarios, y que para el supuesto en que no se sometan a tales Juntas o éstas no sean competentes se establecerá un procedimiento conforme al cual los usuarios finales podrán someter a la Administración del Estado - Ministerio de Industria - tales controversias (dicho procedimiento deberá ser rápido, gratuito y con un plazo máximo para su resolución expresa transcurrido el cual se podrá entender desestimada la reclamación por silencio administrativo, y su resolución será recurrible ante la jurisdicción contencioso-administrativa).

El RESERVICIOS ha concretado estas previsiones legales conforme a este proceso secuencial (art. 38.1): $1^{\circ}$ ) Los operadores, como regla general, deben disponer de un servicio gratuito de atención al cliente para atender y resolver las quejas, reclamaciones y cualquier incidencia contractual que plan-

e) A obtener una compensación por la interrupción del servicio telefónico disponible al público.

f) A contratar la conexión o el acceso a la red de telefonía pública, así como que tales contratos tengan un contenido mínimo (fijado por el RESERVICIOS).

g) A resolver anticipadamente y sin penalización el contrato en caso de modificación de sus condiciones.

h) A que los contratos tipo entre los usuarios y los operadores con obligaciones de servicio público o con poder significativo en el mercado sean sometidos a la aprobación del Ministerio de Industria.

i) A recibir información comparable, pertinente y actualizada sobre la calidad de los servicios de telecomunicaciones disponibles al público.

j) A elegir el medio de pago para el abono de los servicios entre los comúnmente utilizados en el tráfico comercial.

k) A la facturación detallada del servicio telefónico.

1) A la conservación por los abonados de sus números telefónicos.

B) Como derechos específicos de los abonados en materia de protección de sus datos personales.

a) A la cancelación de sus datos de tráfico.

b) A que éstos sean utilizados con fines comerciales sólo con su consentimiento informado.

c) A recibir facturas no desglosadas si así lo solicitan

d) Al tratamiento de sus datos sólo una vez que los mismos hayan sido hechos anónimos o con su consentimiento informado.

e) A impedir la identificación de las llamadas que realicen o reciban.

f) A no recibir llamadas automáticas sin intervención de la voz humana o mensajes de fax con fines de venta directa sin su consentimiento previo e informado, etc.

C) Además, el RESERVICIOS —en los aspectos no abordados por él— remite con carácter general la posición de los consumidores y usuarios del servicio telefónico disponible al público, a lo que se derive de los correspondientes contratos de abono o prepago (aunque con sujeción a lo previsto en él en cuanto a tales contratos).

No obstante, pormenoriza determinados aspectos del servicio telefónico disponible al público: supuestos en que son exigibles los depósitos en garantía; suspensión temporal y definitiva del servicio telefónico fijo por falta de pago (la primera, en un mes tras el cargo y previo aviso, no alcanzará a las llamadas entrantes y las salientes de emergencia; la segunda, a los tres meses de impago o dos suspensiones temporales, previo aviso y con la consecuente resolución del contrato); de otra parte, el abonado tiene derecho a obtener del operador la suspensión temporal del servicio por un período entre 1 y 3 meses. 
LA REGULACIÓN DE LAS TELECOMUNICACIONES Y LA ADMINISTRACIÓN LOCAL

teen sus clientes (este servicio remitirá al Ministerio de Industria copia de las actuaciones realizadas respecto a la correspondiente reclamación). $2^{\circ}$ ) Los usuarios deben formular al operador sus quejas o reclamaciones en el plazo de un mes desde el momento en que tengan conocimiento del hecho que las motive, y si en el plazo de otro mes no hubieran obtenido del operador respuesta satisfactoria, podrán acudir a las vías que siguen. $3^{\circ}$ ) Los usuarios finales podrán entones dirigir su reclamación a las Juntas Arbitrales de Consumo en los términos establecidos en su normativa reguladora. $4^{\circ}$ ) $\mathrm{Si}$ el operador o el abonado no se sometieran a dichas Juntas, podrán dirigirse en el plazo de tres meses desde la respuesta del operador, de la finalización del plazo para responder o de la notificación de la no aceptación del arbitraje por el operador, a la Secretaría de Estado de Telecomunicaciones, que dictará resolución sobre la cuestión planteada en el plazo de 6 meses. La resolución agotará la vía administrativa y contra ella podrá interponerse recurso contencioso-administrativo.

\subsection{La garantía de los derechos de los usuarios como de carácter público}

Como hemos visto, la configuración concreta de los derechos de los usuarios por la LGTEL responde a una impronta casi indistinta con los derechos generales de los consumidores, y los mecanismos para su defensa se articulan asimismo con ese esquema casi privatista de la resolución de un conflicto bilateral, aunque sujeto a una final supervisión administrativa recurrible ante la jurisdicción contencioso-administrativa.

Sería esta última una prueba del tinte público que, al menos textualmente, cabría derivar de la rúbrica que en la LGTEL enmarca tales derechos: «derechos de carácter público» (cf. la del Título III, y en especial la del capítulo III de éste). Pero, como hemos dicho, en el repertorio de derechos sistematizados como tales no se recogen por la Ley los correspondientes a la posición de los usuarios y que, correlativos de las obligaciones de servicio público y el servicio universal, derivan de éste y con carácter vinculante en cuanto a su satisfacción para los operadores que las tengan impuestas (sin más por tratarse de obligaciones de servicio público). Por ello entiendo que de dicha omisión no puede derivarse la inaplicación a tales derechos del comentado procedimiento de resolución de conflictos. Pero, además (ante el incumplimiento del operador encargado del servicio universal que menoscabara los correlativos derechos de los usuarios) hay que tener en cuenta los otros remedios para su garantía que «a fortiori» se derivan de su propio régimen jurídico específico.

En primer lugar, el Ministerio de Industria es responsable de la supervisión del cumplimiento de las obligaciones de servicio público y por tanto del servicio universal (la CMT limita su competencia, en esencia, a los aspectos financieros del servicio universal), competencia ministerial que se extiende 
a la función inspectora y sancionadora (a tener en cuenta que el incumplimiento de las obligaciones de servicio público se tipifica por la LGTEL como infracción administrativa grave o muy grave). Al límite, por lo demás, y como ya hemos visto, la Administración estatal está habilitada para asumir excepcional y transitoriamente la gestión directa o la intervención de un determinado servicio de telecomunicaciones. Por ello la denuncia ante el Ministerio de Industria de los incumplimientos de los operadores podrá dar curso a las oportunas actuaciones de éste que resuelvan la cuestión, al igual que los correspondientes recursos administrativos y contenciosos ante la respuesta insatisfactoria, silencio o inactividad de la Administración.

\section{LA ACTIVIDAD PRESTACIONAL DE LAS CORPORACIONES LOCALES EN EL SECTOR DE LAS TELECOMUNICACIONES}

Analizada la regulación de las telecomunicaciones, abordamos ahora la incidencia de la misma sobre las Corporaciones locales, en los tres planos a los que, según vimos más atrás, podía reconducirse la acción de las Administraciones públicas en este sector.

\section{Las Administraciones como operadores de telecomunicaciones}

Según dispone la LGTEL (artículo $8^{\circ} .4$ ), las Administraciones públicas, directamente o a través de sociedades en cuyo capital participen mayoritariamente, podrán explotar redes y prestar servicios de telecomunicaciones conforme a lo dispuesto en dicha ley y sus normas de desarrollo. En suma, una vez liberalizadas las actividades del sector (y salvo la excepción ya citada de la asunción excepcional y transitoria por el Estado de redes y servicios determinados bajo el régimen del servicio público en sentido estricto), la Ley contempla la posibilidad de que las distintas Administraciones públicas puedan actuar como un operador más, ajustándose al régimen general de las telecomunicaciones.

Dicho régimen general permite el desarrollo de las actividades del sector por cualquier persona física o jurídica — por tanto también las personas jurídicopúblicas - ajustándose a las condiciones legales; según vimos, si son en autoprestación, sin requisito añadido alguno, y si son a favor de terceros, con la simple exigencia de su notificación previa a la CMT (art. $6^{\circ} .1$ y 2 LGTEL). Ahora bien, dado el riesgo para la libre competencia que de suyo podría tener esa actuación de las Administraciones públicas como operadores, la LGTEL (artículo $8^{\circ} .4$ ) precisa que dicha actuación «se realizará con la debida separación de cuentas y con arreglo a los principios de neutralidad, transparencia y no discriminación» y que «la CMT podrá imponer condiciones especiales que garanticen la no distorsión de la libre competencia». 
LA REGULACIÓN DE LAS TELECOMUNICACIONES Y LA ADMINISTRACIÓN LOCAL

La actuación de las Administraciones públicas como operadores de telecomunicaciones plantea de entrada el que aquéllas, en un régimen ya liberalizado - despublificado - de las telecomunicaciones como el vigente, quisieran mediante esa vía proseguir —en el caso de la Administración estatalo asumir —en el de las demás Administraciones- un cierto papel protagonista. Sobre todo si pretendieran hacerlo pertrechadas de su natural impronta, medios y capacidad financiera en tanto que poderes públicos, y afectando así al principio de libre competencia efectiva y a la posición de los operadores privados concurrentes. La cuestión es, pues, relevante, en mayor medida porque el desarrollo de actividades de telecomunicación por la Administración, en concreto, por las Corporaciones locales (directamente, a través de entidades instrumentales e incluso de operadores privados actuantes como contratistas con ellas) se ha convertido en una realidad o una hipótesis barajada con creciente interés. Dentro — esta es la cuestión — del panorama un tanto confuso en cuanto al encaje jurídico del supuesto derivado tanto del estricto tenor textual de la LGTEL, como no menos de otros factores concomitantes.

Entre éstos, la creciente voluntad servicial de los entes locales expresa en los últimos tiempos en muy diversos campos de actividad concurrente - que no en estricta competencia - con los privados; la utilización a tal fin de un variado abanico de formas instrumentales; la dinámica contradictoria entre la liberalización de actividades, con la privatización de antiguas empresas públicas, en el ámbito estatal, y el mantenimiento, cuando no la expansión de éstas, en el caso de las demás Administraciones territoriales; la escasa tradición en nuestro país de la libre competencia y sus implicaciones como marco fundamental del modelo económico, vinculante también para las Administraciones salvo que actúen específicamente legitimadas al efecto; o, en fin, el valor entendido de la transustanciación de la colectividad y sus intereses en la correspondiente Administración, valor entendido que está en la base de la identificación de «lo público» —entendido como lo que afecta a la colectividad, y no hay que olvidar que es característico en las redes y servicios de telecomunicaciones su apertura y oferta al público- y lo que corresponde a la Administración pública.

Por todo ello se trata, pues, de acotar los límites de esa actuación de las Administraciones como operadores de telecomunicaciones, es decir, como unos agentes más de esa actividad concurrentes con los agentes privados. En ese sentido, y en principio, entiendo que la actuación de las Administraciones como operadores de telecomunicaciones, explotando redes o prestando servicios de telecomunicaciones a favor de terceros, por constituir expresión de la iniciativa pública en la actividad económica (que permite el art. 128.2 CE), para empezar habrá de sujetarse a los procedimientos legales internos necesarios (en el caso de los entes locales, pues, a los previstos por la legislación local a tal fin). En segundo lugar, en su actividad como operadores, «en el mercado», las Administraciones deberán respetar el principio de transparen- 
cia financiera y al cabo el régimen de las ayudas de Estado (a ello sirven esas previsiones específica de la LGTEL sobre la necesaria separación de cuentas, transparencia, neutralidad y no discriminación). En fin, dicha actividad no ha de distorsionar la libre competencia, extremo para cuya garantía la CMT puede imponer a la correspondiente Administración — como hemos visto impone el art. $8^{\circ} .4$ LGTEL- condiciones especiales cuyo cumplimiento aquella bien podría controlar al hilo de la constatación de las notificaciones que para poder operar han de remitirle los operadores (incluidas las Administraciones cuando actúen como tales) y sobre todo en su función de supervisión general del mercado y los mercados de referencia. Todo ello para que la actuación de las Administraciones «como un operador más» sea efectivamente tal, en libre competencia y sin prevalerse de los privilegios característicos de la Administración cuando actúa como poder público.

\section{La posición singular de las Corporaciones locales}

No cabía descartar en todo caso que las previsiones textuales de la LGTEL que acabo de glosar pudieran ser objeto de una interpretación no exactamente coincidente con la expuesta. Por ejemplo, que en el desarrollo por los entes locales de auténticas actividades de prestación de servicios de telecomunicaciones a terceros, si éstos fueran sus vecinos, se viera, sobre la base de esa idea de la «transustanciación» de la colectividad local — vecinal— en la entidad local, una suerte de «autoprestación», o que si ello tuviera lugar, aun a terceros como son los vecinos, sin contraprestación económica por parte de éstos, se entendiera que dicha actividad del ente local no constituye una actividad comercial y con la consecuencia de resultar entonces ajena al mercado y por ende al régimen general de las telecomunicaciones. Tengamos en cuenta que, conforme a la LGTEL, las actividades en autoprestación que lleve a cabo cualquier persona, por tanto también una Administración pública, no requieren ser notificadas a la CMT (aunque, sin perjuicio de lo que ahora se dirá, la posibilidad de que la CMT imponga a las Administraciones que actúen como operadores condiciones especiales para garantizar la no distorsión de la libre competencia, se contempla por la LGTEL - art. $8^{\circ}-4$ - con carácter general y sin distingos por razón de que aquéllas realicen la actividad en autoprestación o a terceros).

Pues bien, sin duda para solventar tales dudas, el RESERVICIOS aprobado en 2005 ha venido a concretar el régimen y alcance de la actuación de las Administraciones como operadores de telecomunicaciones. A tal fin, en primer lugar (art. $4^{\circ} .1$ ) matiza el texto del artículo $8^{\circ} .1$ de la Ley al recordar que

«En la explotación de redes o servicios de comunicaciones electrónicas por las Administraciones públicas con contraprestación económica —este es el matiz textual- serán de aplicación las condiciones impuestas, en su caso, por la CMT para garantizar la libre competencia». 
LA REGULACIÓN DE LAS TELECOMUNICACIONES Y LA ADMINISTRACIÓN LOCAL

A lo que, en segundo lugar, añade:

«La prestación transitoria por las entidades locales a sus ciudadanos de servicios de comunicaciones electrónicas de interés general sin contraprestación económica precisará su comunicación previa a la CMT. Cuando ésta detecte que dicha prestación afecta al mercado, en función de la importancia de los servicios prestados, de la existencia en ese ámbito territorial de condiciones de mercado que permitan el acceso a dichos servicios o de la distorsión de la libre competencia, podrá imponer condiciones específicas a dichas entidades en la prestación de los servicios conforme al párrafo anterior».

Con estas determinaciones el RESERVICIOS precisa el alcance del artículo $8^{\circ} .4$ LGTEL respecto a la explotación de redes y prestación de servicios de telecomunicaciones a terceros por las Administraciones públicas con estas especificaciones en cuanto a su régimen y supervisión por la CMT: si esa actividad por parte de cualquier Administración tiene lugar con contraprestación económica se sujetará sin mayores especificaciones al régimen general de la explotación de tales redes y servicios (en su caso con las condiciones impuestas por la CMT para garantizar la libre competencia); y si la lleva a cabo específicamente una Corporación local y la prestación no tiene lugar con contraprestación económica, entonces la actividad también ha de ser previamente comunicada por el ente local a la CMT, la cual, si considera que ello «afecta al mercado», podrá entonces imponer al ente local condiciones específicas a tal fin.

En todo caso, y por encima de su aparente simplicidad, estas previsiones del RESERVICIOS nos acotan ya de modo claro el régimen sustantivo de la actuación de las Corporaciones locales como operadores de telecomunicaciones, pues:

$\left.1^{\circ}\right)$ Viene a admitirse legalmente que los entes locales presten servicios de telecomunicaciones a terceros de carácter gratuito, sea con esas condiciones específicas que puede imponerles la CMT o sin ellas (si la CMT considera que tal prestación gratuita no afecta al mercado).

En principio esta solución podría ser discutible, pues la ausencia de contraprestación económica por el servicio prestado por parte del ente local no significa que el mismo no sea financieramente cubierto mediante los presupuestos locales, incidiendo así en los operadores privados concurrentes que pudieran prestarlo mediante precio, y al cabo en la libre competencia e incluso el propio modelo regulatorio. Sin embargo, las previsiones del RESERVICIOS solventan -o quieren solventar- este obstáculo porque la CMT en ese supuesto (es decir, porque, aun habiendo «mercado» y a pesar de que éste quedara «afectado», y a la vista de los factores citados: la importancia de los servicios prestados por el ente local, la existencia de ese ámbito territorial de condiciones de mercado que permitan el acceso a dichos servicios, es decir, 
su prestación adecuada por otros operadores, la distorsión de la competencia) y para garantizar que no se distorsione la libre competencia, podrá imponer al ente local las correspondientes condiciones específicas.

$2^{\circ}$ ) En todo caso esa posibilidad de prestación gratuita de servicios de telecomunicaciones por los entes locales (no por las demás Administraciones, sujetas éstas sin excepción al régimen general de prestación con contraprestación económica) se circunscribe a los que presten «a sus ciudadanos» (hay que entender sus vecinos) y además debe tener lugar de manera transitoria (cabe sobrentender, hasta que exista posibilidad de acceso comercial adecuado a ese tipo de servicio en el correspondiente ámbito).

$3^{\circ}$ ) Por tanto, más allá de ese supuesto (en el que deberán cumplirse tales requisitos y circunstancias, así como las condiciones específicas que en garantía de la libre competencia les imponga la CMT), los entes locales no podrán prestar servicios de telecomunicaciones a terceros que no lo sean mediante contraprestación económica y sujetos al régimen general — «comercial»- común.

En definitiva, el RESERVICIOS, aunque, como no podía ser menos, refrenda el tenor de la Ley (la actuación de las Administraciones públicas como operadores de telecomunicaciones queda sujeta al régimen general y comercial de mercado y libre competencia bajo la supervisióna tal fin de la CMT), ha dejado, no obstante, un portillo para que las Corporaciones locales, sólo éstas, presten a sus vecinos servicios de telecomunicaciones con carácter gratuito, aunque sólo de manera transitoria. A tal fin deberán comunicarlo a la CMT, la cual podrá imponerles condiciones en garantía de la libre competencia atendiendo a que los servicios sean «importantes», a que en ese ámbito local pueda accederse comercialmente a los mismos servicios, o a que - aun fuera de estas circunstancias- se distorsione con ello la libre competencia.

Las consideraciones anteriores - de alcance general- creo explicitan sin más el campo expresa y específicamente reconocido al municipio de Barcelona por la reciente Ley 1/ 2006, de 13 de marzo, por la que se regula su Régimen Especial, cuyo art. 15 dispone: «1. El Ayuntamiento de Barcelona, como entidad prestadora de servicios públicos basados en infraestructuras físicas de carácter contínuo, podrá instalar redes propias de telecomunicaciones diferentes de las de otros operadores. 2. La utilización de estas redes podrá ser para uso propio o de terceros, con sujeción, en este último caso, a los principios de neutralidad, transparencia y no discriminación y al cumplimiento de los requisitos exigidos por la normativa estatal vigente en materia de telecomunicaciones». En suma, por las previsiones del ordenamiento estatal, en los términos de las consideraciones expuestas, sobre la acción de las Administraciones locales como operadores de redes y prestación de servicios de telecomunicaciones (en autoprestación o a terceros). Y sin que, a nuestro juicio, esa referencia textual — «como entidad prestadora de servicios públicos...»— 
LA REGULACIÓN DE LAS TELECOMUNICACIONES Y LA ADMINISTRACIÓN LOCAL

tenga un particular significado, salvo la eventual consideración como «autoprestación» del establecimiento y uso de tales redes por el propio Ayuntamiento no sólo para el funcionamiento de la Corporación como tal (de esta misma, y no de sus entidades instrumentales, pues éstas, al tener personalidad diferenciada, escaparían de esa reconducción a la autoprestación), sino también con carácter instrumental para el desarrollo de las actividades de su competencia («servicios públicos» en este último sentido).

\section{Servicios de telecomunicaciones y servicios locales}

Lo expuesto describe suficientemente el papel a desempeñar por las Corporaciones locales como prestadores de servicios de telecomunicaciones, unos servicios que prestados por aquéllas como «operadores» y por ende sujetos, con los matices comentados, al régimen general de las telecomunicaciones serán - salvo que sean en autoprestación-, al igual que los que preste cualquier operador, servicios «disponibles al público». Conviene subrayarlo, por la posible confusión de conceptos que puede producirse en torno a la noción de «servicios» y de « servicios públicos», y, en concreto, contextualizadas estas nociones con las competencias reconocidas a los entes locales por la vigente LBRL.

Como es sabido, en la noción de «servicio público» pueden distinguirse diversas acepciones:

a) Una amplia, equivalente a actividad propia de la Administración pública (es el sentido que el concepto tiene en la regulación legal de la responsabilidad patrimonial de la Administración).

b) Otra restringida, como actuación de la Administración consistente en efectuar prestaciones que satisfagan una necesidad sentida colectivamente, en la que, a su vez, cabe distinguir las siguientes.

c) El servicio público en sentido clásico o estricto, como actividad reservada con carácter general y en abstracto a la titularidad de la Administración y que esta desarrolla en gestión directa o indirecta, y de cuyo desarrollo por tanto están excluídos los particulares, salvo que lo hagan a título de esa gestión indirecta (es el sentido con que se ha interpretado recoge el concepto el RSCL o la LCAP).

d) Los llamados servicios públicos «concurrentes» o «compartidos», porque la actividad, que no está reservada a la titularidad de la Administración, es desarrollada, sin embargo, de modo concurrente al tiempo por aquélla y por los particulares, éstos, no en virtud de concesión, sino de su libre iniciativa aunque sujetos a una fuerte reglamentación, por lo que - se diceen este caso los particulares llevan a cabo un servicio público en sentido «objetivo» o «impropio» (es lo que sucede en toda una serie de campos de la acción administrativa: sanidad, educación, etc.). 
e) El «servicio universal» y otros servicios con «obligaciones de servicio público», supuesto éste en que (en sectores liberalizados de su antigua configuración como servicio público en sentido estricto, como sucede con el de las telecomunicaciones), aunque la regla general, vinculante incluso para la actuación eventualmente concurrente de las Administraciones públicas, sea ya el desarrollo de la actividad en virtud de la libre iniciativa - privada, pública- y en libre competencia, la garantía de los fines que antes se aseguraban con el servicio público en sentido estricto (su universalidad, continuidad, calidad determinada, igualdad en su acceso y disfrute, y precio asequible) se logra con la imposición a un operador privado concurrente, de determinadas obligaciones, «obligaciones de servicio público»a tal fin.

De esta manera el servicio público «objetivo» - como «servicio universal»— habría sustituído al anteriormente servicio estricto o «subjetivo». Es lo que explica que la LGTEL (art. 20.2) prevea la aplicación a la imposición de obligaciones de servicio público, y por tanto al servicio universal, con carácter supletorio, del régimen sobre la concesión de servicio público de la LCAP.

Será la legislación específica aplicable al sector de que se trate la que nos demarque el alcance que en el mismo tenga la noción de servicio público. Pues bien, en la actual regulación de las telecomunicaciones no cabe hablar de servicio público en sentido estricto más que en los supuestos de excepción (asunción transitoria de la gestión directa o intervención de determinadas redes y servicios) atribuídos a la Administración estatal a que ya nos referimos más atrás. En todo lo demás la actividad se desarrollará por los operadores privados - y las Administraciones si actúan como éstos- en virtud de su libre iniciativa y en libre competencia, aunque, en su caso, puedan ser designados para prestar, como carga adicional, el «servicio universal».

No cabe por ello, en principio, que la Administración local reconduzca el desarrollo por la misma de tales actividades de telecomunicación a favor de terceros, y a título de «servicios locales», a las cláusulas de atribución de competencia de la vigente LBRL (la cláusula genérica de su artículo 25.1; la de la participación competencial del 25.2 - donde hoy por hoy no se incluyen las telecomunicaciones-, o la de las competencias o servicios mínimos del 26). Aunque sí podrá llevarlas a cabo al amparo del art. 86 -iniciativa pública para el ejercicio de actividades económicas-, en todo caso en régimen de libre concurrencia. Al cabo es esta hipótesis la que refrenda la propia LGTEL al contemplar, según ya hemos visto, la explotación de redes y prestación de servicios por la Administración y las Corporaciones locales, como operadores de telecomunicación en libre competencia, y ello en los términos precisados por el RESERVICIOS que acabamos de comentar (reparemos en que la admisión por éste de los servicios prestados por los entes locales con carácter gratuito, lo es en la medida en que sean compatibles con la libre competencia en los términos que fije la CMT). 
Nada obsta en todo caso, precisamente por ello mismo, que una Corporación local pudiera asumir (una vez superado el período transitorio contemplado por la LGTEL en que el mismo queda «ex lege» asignado a Telefónica) la condición de prestador del servicio universal para una zona geográfica determinada, para alguno de los elementos que lo integran, etc. Ciertamente ajustándose a los procedimientos correspondientes (resultar designado como tal en la correspondiente licitación pública, o serlo directamente) y a los requisitos legales a tal fin establecidos por la regulación de las telecomunicaciones. De estos últimos conviene retener que para poder presentarse a dicha licitación - art. 37.3 RESERVICIOS - hay que tener la condición de «empresa legalmente establecida» (lo que parece restringir esa hipótesis al caso de las entidades públicas empresariales o las sociedades mercantiles locales) y «debidamente autorizada para la prestación del elemento de servicio universal al se refiere el concurso» (es decir, que venga ya prestando el servicio o elemento de éste de que se trate).

\section{LOS ENTES LOCALES COMO TITULARES DE COMPETENCIAS DE REGULACIÓN CONCURRENTE CON LA DE LAS TELECOMUNICACIONES}

\section{La concurrencia normativa y competencial y su coordinación}

Ya hemos dicho que las telecomunicaciones constituyen una materia de la competencia estatal exclusiva (art. 149.1.21 CE). Pero, por definición, los servicios prestados mediante las redes de telecomunicación y estas mismas y sus infraestructuras tienen una lógica dimensión o incidencia física y espacial. Se plantea así el problema de la disponibilidad por los operadores de telecomunicaciones del correspondiente espacio físico (de dominio público o de propiedad privada) necesario para la instalación de aquéllas, así como el del ajuste de dicha actividad a ámbitos normativos y de la competencia material (ordenación del territorio, urbanismo, medio ambiente, salud pública, etc.) de otras Administraciones distintas de la del Estado, que, en su caso, pueden condicionar aquélla al cumplimiento de determinados requisitos y al control preventivo (mediante las correspondientes autorizaciones, licencias, etc.) de esas Administraciones. En el caso de la Administración autonómica como exigencia del bloque de la constitucionalidad (sin perjuicio de su necesario encuadre en la normativa básica en su caso aplicable: así en materia de medio ambiente, de protección de la salud, etc.) y en el de las Corporaciones locales como consecuencia del ámbito competencial que a éstas les reconoce la legislación de régimen local.

Lo que esa normativa (simplificaremos llamándola «específica», como distinta de la general de las telecomunicaciones) pueda establecer al respecto habrá que derivarlo de lo establecido en cada caso por el correspondiente 
ordenamiento aplicable, como tal disperso y plural en la medida que la competencia en los citados ámbitos pertenece de manera preponderante a las diferentes Comunidades Autónomas y, en su parcela, a cada una de las Corporaciones locales.

En el campo de la ordenación del territorio, materia, como es sabido, de la competencia exclusiva de las Comunidades Autónomas, la legislación de éstas en general prevé que los instrumentos de planificación territorial contemplen la oportuna articulación del sistema de telecomunicaciones y suele recoger los correspondientes mecanismos de coordinación con la Administración estatal (por ejemplo, informe preceptivo de ésta para la planificación territorial por la Comunidad Autónoma, e informe preceptivo de la última para la planificación de las infraestructuras de telecomunicación por la Administración del Estado).

También el urbanismo es una competencia exclusiva de las Comunidades Autónomas - sin perjuicio de los títulos singulares de intervención que corresponden al Estado y la competencia concurrente de los entes locales-, por lo que las previsiones de la normativa urbanística con incidencia sobre las infraestructuras de telecomunicaciones habrá que derivarlas de la correspondiente legislación autonómica (que suele exigir como contenido necesario de los planes urbanísticos la funcionalidad, economía y eficacia de las redes e infraestructuras de comunicaciones) y del consecuente entramado normativo piramidal de dichos planes. A nivel estatal la LRSV de 1998 no aborda la cuestión y sólo fragmentariamente lo hacen, y subsidiariamente como les corresponde, el Texto Refundido de la Ley del Suelo de 1976 y el Reglamento de Disciplina Urbanística de 1978 , aunque, como veremos, y al igual que para la normativa de ordenación del territorio, la propia LGTEL (art. 26 y ss.) incluya previsiones determinantes al respecto.

En cuanto al medio ambiente (dejamos los aspectos relativos a la salud pública para una consideración ulterior), materia aquélla articulada, como es sabido, conforme al esquema bases estatales y desarrollo y normas adicionales de protección de las Comunidades Autónomas, más una competencia concurrente de los entes locales (arts. 25 y 26 LBRL), se produce una situación similar. Por lo demás, la normativa medioambiental ofrece un panorama muy dispar en su fundamentación y concretas previsiones sobre las telecomunicaciones: en algún caso utiliza específicamente el título del medio ambiente para regular particularmente la instalación de las infraestructuras en determinados ámbitos como parques, parajes naturales, etc. (es el caso, por ejemplo, de la normativa reglamentaria de Andalucía) o las instalaciones de telefonía móvil y otras instalaciones de radiocomunicaciones en general (caso de la de Cataluña); en otros la normativa autonómica utiliza una pluralidad de títulos competenciales —ordenación del territorio, urbanismo, medio ambiente, etc. - para regular también particularmente las instalaciones radioeléctricas de telefonía móvil (caso de Castilla — La Mancha), etc. 
LA REGULACIÓN DE LAS TELECOMUNICACIONES Y LA ADMINISTRACIÓN LOCAL

Por lo que respecta a las Corporaciones locales, en su ámbito competencial definido por la LBRL y, en su caso, por la legislación local y sectorial, las mismas disponen, como hemos dicho, de competencias concurrentes. De manera que, aun legitimados los operadores por la habilitación que les confiere la LGTEL y los derechos que ésta les otorga, deberán sujetarse a la reglamentación local de que se trate, como después analizaremos.

En cualquier caso, esa dispersión normativa y competencial, así como la diversidad y número de las Administraciones implicadas (estatal, autonómicas, locales), evidenciada especialmente con el ejercicio intensivo y repentizado de la competencia de las últimas - a partir de sus diferentes títulos de intervención: del dominio público al urbanismo - ante algunas situaciones específicas de extrema complejidad burocrática, como la producida con el tendido de las infraestructuras de cable, e incluso de alarma social como la suscitada en torno a la incidencia sobre la salud de las estaciones base de telefonía móvil, pusieron de manifiesto, ya con la LGTel de 1998, la descoordinación normativa y entre Administraciones existente y su repercusión en un desarrollo funcional de las telecomunicaciones.

No puede por ello extrañar que la LGTEL de 2003 abordara la cuestión, con una clara mejora de las técnicas de aquélla y desde una evidente preocupación por la seguridad jurídica, estableciendo a tal fin «criterios generales a respetar por todas las Administraciones públicas» (cf. su E. de M.), luego desarrollados por el RESERVICIOS de 2005 tomando como punto de referencia el derecho de los operadores de telecomunicaciones a la ocupación del dominio público y la propiedad privada.

\section{Competencias sobre las infraestructuras}

\subsection{Ocupación por los operadores del dominio público y la propiedad privada}

\section{a) El derecho de los operadores a la ocupación}

La LGTEL reconoce a los operadores de telecomunicaciones el derecho a la ocupación del dominio público en la medida que sea necesario para el establecimiento de la correspondiente red de comunicaciones electrónicas (art. 26). Para ejercer este derecho podrán dirigirse a la CMT a fin de que en plazo de 6 días les expida certificación de su condición de operadores (es decir, de estar inscritos en el Registro de operadores) (art. 31 LGTEL). Precisamente para que ese derecho pueda resultar efectivo, los instrumentos de planificación territorial y urbanística que aprueben las distintas Administraciones (Comunidades Autónomas, entes locales) han de recoger las necesidades de redes públicas de telecomunicaciones contenidas en el informe previo y vinculante del Ministerio de Industria que sobre tales necesidades, en el co- 
rrespondiente ámbito territorial, deben recabarle los órganos redactores de tales instrumentos (art. 26.2).

En términos similares reconoce también la LGTEL a los operadores el derecho a la ocupación de la propiedad privada cuando ello resulte estrictamente necesario para la instalación de la correspondiente red en la medida prevista en el proyecto técnico presentado y siempre que no existan otras alternativas económicamente viables, ya sea a través de su expropiación forzosa o mediante la declaración de servidumbre forzosa de paso para la instalación de infraestructuras de redes públicas de comunicaciones electrónicas. A tal fin los operadores tendrán la consideración de beneficiarios en los expedientes que se tramiten, y la aprobación del proyecto técnico por la Administración del Estado - previo informe preceptivo de la Comunidad Autónoma - llevará implícita la declaración de utilidad pública y la necesidad de la ocupación.

¿Conduce esta tesitura — al cabo la actuación del Ministerio de Industria como expropiante - a la irrelevancia de otras posibles actuaciones concurrentes de la Administración local? Visto el respeto por la LGTEL (art. 28.2) del necesario ejercicio concurrente de las competencias de los entes locales en materia de urbanismo, entiendo que la resolución del expediente por el Ministerio de Industria no excluye ni impide — sin perjuicio del obligado respeto de la legislación de telecomunicaciones como legislación sectorial- esas intervenciones de las Corporaciones locales que — aunque no ligadas directamente al hecho expropiatorio- deban producirse sobre los efectos derivados de éste y así estén previstas por el ordenamiento: en concreto, la necesidad de licencia o el correspondiente acto de control preventivo (arts. 84.1 y 4, y 25. d) LBRL; y $1^{\circ}$, ap. 3 y 5 y $21^{\circ}$ RSCL) y las que prevea el ordenamiento urbanistico sobre los actos de uso del suelo ${ }^{16}$.

Ahora bien, de otra parte y como contrapartida de ese derecho de ocupación, el art. 30 LGTEL regula la ubicación compartida y el uso compartido por diversos operadores de la propiedad pública o privada necesaria para la instalación de las correspondientes redes. En efecto, si los operadores no pueden ejercer por separado tal derecho por no existir alternativas debido a motivos justificados en razones de medio ambiente, salud pública, seguridad pública u ordenación territorial o urbana, la Administración competente en dichas materias, previo trámite de información pública, acordará la utilización compartida del dominio público o la propiedad privada en que se vayan a establecer las redes, o el uso compartido de las infraestructuras en que se vayan a apoyar tales redes, según resulte necesario (art. 30 LGTEL y 51 RESERVICIOS).

\footnotetext{
16 Por lo demás, la Ley 3/ 1976, de 11 de marzo, sobre expropiación forzosa e imposición de servidumbre de paso de líneas, cables y hacer hertzianos para los servicios de telecomunicaciones, sujeta la servidumbre de paso subterráneo a las condiciones que determinen las ordenanzas locales (art. $3^{\circ}$.2) y proclama (art. $2^{\circ} .3$ ) que la competencia del Estado para el reconocimiento de los derechos de expropiación y servidumbre de paso de líneas se entiende sin perjuicio de las competencias de los entes locales cuando las instalaciones se hayan de establecer en suelo urbano o urbanizable o afecten a servicios, obras o actividades cuya gestión les corresponda.
} 
LA REGULACIÓN DE LAS TELECOMUNICACIONES Y LA ADMINISTRACIÓN LOCAL

El uso compartido se articulará mediante acuerdo entre los operadores interesados, y a falta de acuerdo, las condiciones del uso compartido se establecerán por resolución de la CMT, previo informe de la citada Administración competente, cuyos contenidos calificados por este informe de esenciales para la salvaguarda de los intereses públicos cuya tutela tenga encomendados se incorporarán a dicha resolución. Por otra parte, en el caso específico del uso compartido de instalaciones radioeléctricas emisoras, cuando de ello se derivara la obligación de reducir los niveles de potencia de emisión (niveles incrementados precisamente como consecuencia del uso compartido y que puedan superar «los límites permitidos para el uso compartido» que se fijen al amparo del art. 44.1.a) LGTEL) entonces deberán autorizarse más emplazamientos si son necesarios para garantizar la cobertura de la zona de servicio.

\section{b) El control preventivo y la normativa de los entes locales: límites}

La voluntad de coordinación normativa y administrativa que preside las previsiones de la LGTEL que analizamos se manifiesta además en que el reconocimiento por ésta del derecho de los operadores a la ocupación del dominio público y la propiedad privada se hace compatible con el respeto de la normativa específica distinta de la de las telecomunicaciones que corresponda, y con las intervenciones de las distintas Administraciones habilitadas por esa normativa específica. Y así, de una parte, para el ejercicio de su derecho de ocupación los operadores deberán obtener las correspondientes autorizaciones o concesiones administrativas derivada de esa normativa específica: en concreto, la normativa relativa a la gestión del concreto dominio público de que se trate y la regulación dictada por la Administración pública titular de éste en los aspectos atinentes a su protección y gestión (art. 28.1 LGTEL), así como la dictada por las Administraciones públicas en materia de medio ambiente, salud, pública, seguridad pública, defensa nacional, ordenación urbana o territorial y tributación por ocupación del dominio público (art. 28.2 LGTEL).

Pero, de otra, esa normativa específica debe quedar reintegrada y articulada con ese derecho de ocupación. Todo ello (y como bien expresivos del necesario respeto por los entes locales de la legislación sectorial y del principio de colaboración y actuación concurrente con la Administración estatal conforme al art. 84.3 LBRL) en los siguientes términos (art. 29 y ss. LGTEL):

$1^{\circ}$ La normativa específica (sobre el dominio público, medioambiental, de salud pública, seguridad pública, defensa nacional, ordenación urbana o territorial, y tributación por ocupación del dominio público) debe reconocer el derecho de los operadores de telecomunicaciones a la ocupación del dominio público o de la propiedad privada. Ahora bien, dicha normativa podrá, no obstante, imponer condiciones al ejercicio de tal derecho justificadas por 
razones de protección del medio ambiente, la salud pública, la seguridad pública, la defensa nacional o la ordenación urbana o territorial. Aunque en todo caso las limitaciones que entrañen para el ejercicio de ese derecho deberán resultar proporcionadas en relación con el concreto interés público que se trate de salvaguardar, y no podrán implicar la restricción absoluta del derecho. Por ello cuando una condición pudiera implicar la imposibilidad, por falta de alternativas, de llevar a cabo la ocupación del dominio público o la propiedad privada, el establecimiento de dicha condición deberá ir acompañado de las medidas necesarias, entre ellas, el uso compartido de infraestructuras, para garantizar así el derecho de ocupación de los operadores y su ejercicio en igualdad de condiciones.

$2^{\circ}$ Además, dicha normativa específica dictada por las correspondientes Administraciones deberá cumplir, al menos, los siguientes requisitos: a) Ser publicada en un diario oficial del ámbito correspondiente a la Administración competente, de cuya publicación y de un resumen de la misma, así como del texto de las ordenanzas fiscales municipales que impongan las tasas por utilización privativa o aprovechamientos especiales constituidos sobre el suelo, subsuelo o vuelo, y de cuantas disposiciones tributarias afecten al dominio público, se deberá dar traslado a la CMT, la cual publicará en Internet un resumen de las normas que cada Administración le haya comunicado. b) Incluir un procedimiento rápido y no discriminatorio de resolución de las solicitudes de ocupación. c) Garantizar que las solicitudes de información que las Administraciones realicen a los operadores sean motivadas, tengan una justificación objetiva, sean proporcionadas al fin perseguido y se limiten a lo estrictamente necesario. d) Garantizar la transparencia de los procedimientos y que las normas aplicables fomenten una competencia leal y efectiva entre los operadores.

$3^{\circ}$ Precisamente en aras de esa garantía de la competencia entre operadores, si las Administraciones competentes según esa normativa específica o titulares del dominio público, a su vez, ostentan la propiedad o ejercen el control directo o indirecto de operadores de redes, deberán mantener una separación estructural entre dichos operadores y los órganos encargados de la regulación y gestión de los comentados derechos (art. 29.3 LGTEL).

En definitiva, el operador de telecomunicaciones queda así, con las garantías de coordinación normativa citadas, sujeto a ese doble bloque normativo y por tanto también a las competencias regulatorias de los entes locales (así lo recuerda el art. 57 RESERVICIOS, añadiendo que el operador deberá sujetarse a los límites de emisión que se establezcan en desarrollo de lo previsto en el art. 44.1.a) LGTEL, es decir, los niveles de emisión radioeléctrica tolerables y que no supongan un peligro para la salud pública).

En las anteriores consideraciones hay que contextualizar, por ejemplo, lo específicamente dispuesto - como expresa concreción para dicho municipiopor la reciente Ley $1 / 2006$, de 13 de marzo, por la que se regula el Régimen Especial del municipio de Barcelona, que en su art. 12 establece: « La 
construcción, ampliación, reforma o alteración de redes de telecomunicaciones a las que resulte de aplicación la Ley 32/2003, de 3 de noviembre, General de Telecomunicaciones, que necesite la utilización del dominio público municipal requerirá la obtención previa de la correspondiente autorización municipal, aunque el nuevo tendido que se realice utilice canalizaciones existentes. Estas autorizaciones se otorgarán de conformidad con lo establecido por el planeamiento urbanístico. Cuando dicho planeamiento no contenga las determinaciones detalladas oportunas, el Ayuntamiento podrá dictar las resoluciones pertinentes para optimizar las canalizaciones y derechos de paso existentes al objeto de establecer su utilización conjunta por parte de diferentes operadores, en el marco de lo establecido por la normativa estatal vigente en materia de telecomunicaciones» (es decir, las previsiones que acabamos de analizar).

\subsection{La cooperación interadministrativa a efectos del despliegue de las redes de radiocomunicación}

El propósito armonizador entre el estatuto de los operadores de telecomunicaciones consagrado por la LGTEL y la aplicación de la normativa específica de competencia de las diversas Administraciones que pueden incidir sobre aquél se reconoce, de otra parte, en las previsiones de la disposición adicional $12^{\mathrm{a}}$ de aquélla relativas al despliegue de las redes de radiocomunicaciones.

Esta disposición adicional contempla la creación, en el marco de lo previsto en los apartados 7 y 8 del artículo 5 de la Ley de Régimen Jurídico de las Administraciones Públicas (LRJPAC), de un órgano de cooperación con la participación de las Comunidades Autónomas (y a cuyas reuniones podrá ser invitada la asociación de las entidades locales de ámbito estatal con mayor implantación) para impulsar, salvaguardando las competencias de todas las Administraciones implicadas, el despliegue de las infraestructuras de radiocomunicación, en especial las redes de telefonía móvil y fija inalámbrica. Todo ello de acuerdo con los principios de seguridad de las instalaciones, de los usuarios y del público en general, la máxima calidad del servicio, la protección del medio ambiente y la disciplina urbanística.

Esta previsión de la LGTEL se dirigía obviamente a que el despliegue de las redes de telecomunicaciones (sobre todo las de telefonía móvil, y en general de las comunicaciones vía radio), que venía sufriendo obstáculos derivados de la dispersión competencial entre las diversas Administraciones implicadas y de la disparidad de criterios y actuaciones al respecto mantenidos por unas y otras, se realizara en el futuro de manera más coordinada, y se solventara así un problema de evidente trascendencia económica y tecnológica sobre el que venían - y han seguido - alertando los operadores.

En todo caso, al deber articularse tal solución orgánica por la vía prevista en el art. $5^{\circ} .7$ y 8 LRJPAC, conviene tener en cuenta, primero, que la misma 
ni mucho menos podría resultar preceptiva y efectiva a partir tan sólo de lo previsto en la LGTEL, sino que a tal fin deberían cumplirse los extremos que ese precepto de la LRJPAC recoge: la creación de ese órgano debería ser «acordada» entre la Administración del Estado y las de las Comunidades Autónomas (en el art. 5 .7 LRJPAC la creación de tales órganos de cooperación se contempla como potestativa), y además, conforme a los apartados 6 y 7 de dicho art. 5 LRJPAC, la incorporación a tal órgano de la representación de las entidades locales — cuestión relevante pues la mayoría de los problemas del despliegue de las redes de radiocomunicación se suscitan en el ámbito local - habría de ser decidida, una vez constituído el mismo, por su Pleno, el cual debería asimismo decidir si dicha incorporación tendría lugar con carácter permanente o sólo según el orden de cada sesión. Y en segundo lugar, que de la sola constitución efectiva de dicho órgano «de cooperación» no podía derivarse sin más la solución del problema. Pues la «cooperación» es por definición voluntaria (como bien lo revela la precisión de la propia disposición adicional $12^{\mathrm{a}}$ LGTEL de que el despliegue de las infraestructuras de radiocomunicación encomendado a dicho órgano se producirá «salvaguardando las competencias de todas las Administraciones implicadas») y porque dado el carácter y funciones de los órganos de cooperación como el que comentamos (ex art. $5^{\circ}$ LRJ-PAC, «de preparación, estudio y desarrollo de cuestiones concretas») es dudoso que en el seno del mismo pudieran adoptarse acuerdos directamente vinculantes en cuanto al fondo para las Administraciones partícipes en él. Por lo que el que esto último pudiera tener lugar parece estaría condicionado a que las oportunas decisiones a tal fin tuvieran lugar a través de los correspondientes convenios, en su caso en el seno de la correspondiente Conferencia Sectorial.

Quizá por ello los problemas para el despliegue coordinado de las redes radioeléctricas y las antenas de telefonía móvil prosiguieron (ese despliegue resulta necesario para el sector: al parecer, hay desplegadas 27.000 antenas, pero serían necesarias otras 5.000 para asegurar un buen nivel de cobertura, y 20.000 para cubrir todo el territorio nacional). De ahí la creación en junio de 2005, por acuerdo de los diversos agentes del sector y las Administraciones autonómicas y locales y auspiciado por el Ministerio de Industria, de un Comité Técnico de Seguimiento del despliegue de las infraestructuras de radiocomunicación como órgano mediador y de supervisión de dicho despliegue. Dicho Comité, en el que estarían representados el Gobierno, las Comunidades Autónomas, la FEMP, la Asociación Española de Empresas de Electrónica y TIC (AETIC) y el Colegio Oficial de Ingenieros de Telecomunicación, debería articular medidas y proponer soluciones para el despliegue ordenado y seguro de tales redes, proporcionando a las Administraciones locales, empresas y colectivos ciudadanos el oportuno referente técnico, legal y sanitario de consulta. A lo que se añadió el acuerdo inicial sobre un llamado «procedimiento de referencia único» con el fin de unificar y simplificar la documentación (plan de despliegue, certificados técnicos de cada instalación, etc.) y los trámites administrativos y sus plazos requeridos por las distintas Administraciones públicas para la 
instalación de las estaciones base y antenas de telefonía móvil (aprobación de la instalación radioeléctrica e informe posterior de su inspección por el Ministerio de Industria, licencias municipales de obra, apertura y en su caso actividad, eventual informe de impacto ambiental, etc.). Todo ello con el objetivo de evitar las demoras y reducir los plazos para la obtención de las correspondientes autorizaciones y licencias (entre las soluciones previstas a tal fin se incluye la presentación simultánea por las operadoras del proyecto técnico que ha de ser aprobado por el Ministerio de Industria y de la solicitud de los correspondientes permisos y licencias municipales).

En cualquier caso la iniciativa se articuló en términos de autorregulación, y si, de una parte, las principales operadoras (Telefónica Móviles, Vodafone, Amena, etc.) se comprometieron a establecer un Código de buenas prácticas con criterios técnicos, medioambientales y paisajísticos para su despliegue, de otra, al parecer el acuerdo no resultaba directamente vinculante para las Corporaciones locales que deberían decidir su específica adhesión a dicho acuerdo.

\section{Otras determinaciones de la normativa estatal con incidencia en el ámbito local}

Además de lo en ella previsto sobre la ocupación del dominio público y la propiedad privada (que, como hemos visto, la armonizan con la aplicación de las normativas específicas de competencia de otras Administraciones, entre ella la local, en virtud de títulos espaciales, medioambientales, etc.) la LGTEL incluye además determinadas previsiones sobre la aplicación de la normativa estatal que, aunque bajo el título competencial de las telecomunicaciones, se dirigen a garantizar ese mismo tipo de objetivos (territoriales, urbanísticos, medioambientales, de salud pública, etc.) y que conviene sintetizar dada su incidencia sobre el ámbito local y las competencias concurrentes de los entes locales. Es el caso del régimen de las infraestructuras comunes de telecomunicación en el interior de los edificios (ICT) y de los límites a las emisiones radioeléctricas.

\subsection{El régimen de las $I C T$}

La LGTEL prevé que mediante Real Decreto se desarrolle «la normativa legal» en materia de infraestructuras comunes de comunicaciones electrónicas en el interior de los edificios, a la cual deberá ajustarse la correspondiente normativa técnica básica de edificación que regule la infraestructura de obra civil en el interior de los edificios (art. 37). La LGTEL, pues, no regula específicamente este apartado, sino que se remite a la normativa legal correspondiente y al desarrollo reglamentario de ésta. 
Esa normativa legal está constituida por el Real Decreto Ley 1/1998, de 27 de febrero (que la LGTEL, disposición adicional $3^{\mathrm{a}}$, mantiene en su vigencia, aunque su art. $1^{\circ} .2$ fue modificado por la Ley 10/ 2005, de 14 de junio, de Medidas Urgentes de Impulso a la Televisión Digital), desarrollado por Real Decreto 401/ 2003, de 4 de abril, por el que se aprueba el Reglamento regulador de la ICT y la Orden CTE 1296/ 2003, de 14 de mayo, para su aplicación. Pero su alcance jurídico es fundamentalmente «civil» (reconoce el derecho de los copropietarios en régimen de propiedad horizontal, y en su caso los arrendatarios, a instalar tales infraestructuras, conectarse a ellas o adaptar las existentes). Lo que no excluye que sus previsiones en algún caso puedan resultar concomitantes o condicionantes de la ordenación de las telecomunicaciones o de la territorial, urbanística, de salud pública o medioambiental, de competencia de otras Administraciones.En este sentido y como determinaciones concomitantes (para la Administración local en su caso), no podrá otorgarse autorización para la construcción o rehabilitación integral de ningún edificio si al proyecto arquitectónico no se une el de la instalación de la infraestructura común, y en edificios ya construídos dicha instalación puede ser obligatoria, además de si el número de antenas instaladas, individuales o colectivas, es superior a un tercio del número de viviendas o locales, cuando la Administración competente considere peligrosa o antiestética la colocación de antenas en el edificio.

En todo caso, es oportuno precisar algún extremo a este respecto. Primero (y como en este contexto la determinaciones del citado Real Decreto Ley 1/ 1998 se han solido entremezclar con el régimen de la telefonía móvil) conviene aclarar que, dada la específica funcionalidad de esas infraestructuras comunes «de acceso a los servicios de telecomunicaciones en el interior de los edificios» (en concreto, los servicios de radio y televisión terrestre, tanto analógica como digital, el servicio telefónico básico y el de telecomunicaciones por cable), las previsiones de dicha normativa en principio no afectan a las infraestructuras de telefonía móvil (algo lógico dado el modo de transmisión —-móvil- de ésta y teniendo en cuenta que las instalaciones de telefonía móvil en los edificios no se dirigen a prestar servicio en el edificio, sino, por el contrario, a articular la red de transmisión a terminales por definición ajenos a ese edificio).

Otra cosa es que, como ahora veremos, la normativa sobre protección radioeléctrica o frente a las emisiones radioeléctricas (no estrictamente la de ICT) pueda incidir o condicionar las infraestructuras de telecomunicación - transmisoras - radioeléctricas ubicadas en los edificios, que las Ordenanzas municipales puedan regular al tiempo - al hacerlo de las instalaciones radioeléctricas- junto a las transmisoras como las de telefonía móvil, las receptoras como las de televisión, evocando por ello parcialmente la regulación de las ICT, o, es más, que los entes locales, en el ejercicio de sus competencias, puedan, y en términos acordes con la normativa estatal sobre las ICT, llevar a cabo una acción concomitante. Esto último es lo que, por ejemplo, ha venido a precisar la Ley 1/ 2006, de 13 de marzo, por la que se regula el Ré- 
LA REGULACIÓN DE LAS TELECOMUNICACIONES Y LA ADMINISTRACIÓN LOCAL

gimen Especial del municipio de Barcelona, al establecer — ciertamente limitando esa acción municipal al ámbito del fomento- en su art. 14 que «el Ayuntamiento de Barcelona fomentará que los ciudadanos puedan disponer de servicios de telecomunicaciones de calidad, que permitan la prestación de servicios avanzados e interactivos, con capacidad de adaptación a la evolución de las tecnologías y prestados en régimen de competencia efectiva. Con este fin promoverá que los cables, equipos e instalaciones que sean necesarios para su prestación puedan llegar a los domicilios en las condiciones establecidas en la normativa vigente».

\subsection{La protección frente a las emisiones e instalaciones radioeléctricas de comunicación}

La LGTEL incluye las correspondientes previsiones sobre la protección del dominio público radioeléctrico y frente a éste. En el primer caso, y con la finalidad del aprovechamiento óptimo del dominio público radioeléctrico, evitar su degradación y mantener un adecuado nivel de calidad en el funcionamiento de los distintos servicios de radiocomunicaciones (art. 32.1), prevé la posibilidad de establecer limitaciones a la propiedad y a la intensidad del campo eléctrico (altura máxima de los edificios, distancia mínima para ublicar industrias o instalaciones de alta tensión, etc.), así como las servidumbres necesarias para la protección radioeléctrica de determinadas instalaciones o el adecuado funcionamiento de las estaciones o instalaciones utilizadas para la prestación de los servicios públicos, por motivos de seguridad pública, o cuando sea necesario en virtud de acuerdos internacionales. Tales limitaciones fueron concretadas, bajo la LGTEL de 1998, por el Real Decreto 1066/2001, de 28 de septiembre, que aprobó el Reglamento por el que se establecen condiciones de protección del dominio público radioeléctrico, restricciones a las emisiones radioeléctricas y medidas de protección sanitaria frente a las emisiones radioeléctricas, norma ésta vigente hoy con las modificaciones introducidas por el Real Decreto 424/ 2005, de 15 de abril, que aprobó el RESERVICIOS.

Pero, además de la protección del dominio público radioeléctrico, la LGTEL (art.32.2) y ese mismo Reglamento prevén la imposición de límites a los derechos de uso del dominio público radioeléctrico con el fin de proteger otros bienes jurídicos prevalentes o servicios públicos que pudieran verse afectados por dicho uso. Es más, la aprobación del Real Decreto 1066/ 2001 - y el contenido del art. 32.2 LGTEL - traen causa de la preocupación, cercana la alarma social, surgida en el año 2001 por la eventual incidencia sobre la salud y el medio ambiente de las emisiones radioeléctricas, en particular las de las estaciones base de telefonía móvil instaladas en o junto a los núcleos de población, y la voluntad de la norma de responder a la cuestión ante la expansión de la telefonía móvil y la actuación dispar al efecto de las Administraciones autonómicas y local. 
Pues bien, el Reglamento citado, dictado al amparo de la competencia del Estado sobre las telecomunicaciones y sanidad (en este último caso con el carácter de norma básica), y aplicable a «las emisiones de energía en forma de ondas electromagnéticas, que se propagan por el espacio sin guía artificial, y que sean producidas por estaciones radioeléctricas de radiocomunicaciones o recibidas por estaciones del servicio de radioastronomía», regula las restricciones a las emisiones radioeléctricas y las medidas de protección sanitaria frentes a éstas (recogiendo a tal fin lo previsto en la Recomendación 199/ 519/ CE).

En concreto, y con el fin de garantizar la adecuada protección de la salud del público en general, establece unos límites de exposición a las emisiones radioeléctricas (figuran en su Anexo II), resultantes de la aplicación de unas «restricciones básicas» de la exposición (fijadas a partir de la densidad de corriente, la absorción de energía por el tejido biológico y la densidad de potencia) y unos «niveles de referencia» (cuyo cumplimiento garantiza el respeto de la restricción básica pertinente) a zonas en las que pueda permanecer habitualmente el público en general (el art. $7^{\circ}$ del Reglamento prevé que dicho Anexo II se adaptará en el futuro a los datos derivados del progreso científico).

Además - y sobre la base de la necesaria autorización por el Ministerio de Industria de toda instalación radioeléctrica- el Real Decreto 1066/ 2001 establece un conjunto de condiciones adicionales para que dicha autorización pueda ser otorgada y tendentes a garantizar el cumplimiento por dichas instalaciones radioeléctricas de esos límites de exposición ${ }^{17}$. En fin, autorizadas dichas instalaciones radioeléctricas, antes de su utilización las mismas deben superar la correspondiente inspección por el Ministerio de Industria, y los operadores remitir a éste cada año certificación expedida por técnico competente de que se han respetado durante el año anterior los límites de exposición.

En relación con estas exigencias debe subrayarse que el Reglamento, como hemos dicho, se afinca en la competencia estatal en materia de telecomunicaciones y sanidad. Por lo que no cabe excluir que en virtud de los títulos competenciales (por ejemplo, ordenación del territorio, medio ambiente, urbanismo, prevención de la salud, etc.) exclusivos o concurrentes de otras Administraciones, éstas puedan establecer medidas adicionales de control. Precisamente desde esa perspectiva concurrencial el Reglamento - cuyas

\footnotetext{
${ }^{17}$ Planificación de las instalaciones por sus titulares teniendo en cuenta una serie de criterios - minimización de los niveles de exposición, en mayor medida sobre los llamados «espacios sensibles» situados a menos de 100 metros; que el diagrama de emisión de las instalaciones situadas en las cubiertas de edificios residenciales no incida sobre el propio edificio; condicionamiento de la compartición por la consiguiente concentración de las emisiones radioeléctricas; prohibición de establecer nuevas instalaciones si se superan los límites de exposición establecidos; los operadores que establezcan redes o presten servicios de redes soporte de radiodifusión y televisión, telefonía móvil, etc. deben presentar un estudio detallado realizado por técnico competente que indique los niveles de exposición radioeléctrica en áreas cercanas a sus instalaciones radioeléctricas fijas en las que puedan permanecer habitualmente personas, etc.
} 
LA REGULACIÓN DE LAS TELECOMUNICACIONES Y LA ADMINISTRACIÓN LOCAL

previsiones se aplicarán en cualquier entorno, urbano o no- establece que el Ministerio de Sanidad - y las autoridades sanitarias de las Comunidades Autónomas a través de éste - tendrán derecho a la información sobre los niveles de exposición resultantes de los proyectos sometidos a autorización (es un derecho a la información por razones sanitarias, materia en la que las Comunidades Autónomas tienen competencia, y no en materia de telecomunicaciones, exclusiva del Estado; y aunque la norma no reconoce idéntico derecho a las Corporaciones locales, cabría interpretar que el mismo derivaría de su posición de interesadas).

\section{Conclusión sobre las competencias de regulación de las Corporaciones locales}

Como hemos visto, la legislación de telecomunicaciones contempla expresa o implícitamente una serie de intervenciones de las Corporaciones locales sobre el establecimiento y explotación de las infraestructuras y redes de telecomunicación, concomitantes con las de la Administración estatal. Resumiendo lo expuesto hasta aquí:

a) Necesidad de que los instrumentos de planeamiento urbanístico sean objeto de un informe preceptivo y vinculante del Ministerio de Industria sobre las necesidades de establecimiento de redes públicas de telecomunicaciones, cuyo contenido deberá ser recogido en dichos instrumentos (art. 26 LGTEL), como expresión sin duda del principio del art. 58.2 LBRL de que las Administraciones competentes para la formulación y aprobación de instrumentos de planificación deben otorgar a las restantes una participación que permita armonizar los intereses públicos afectados.

b) El ejercicio del derecho de ocupación del dominio público local para la instalación y explotación de las infraestructuras de red requiere el correspondiente título demanial habilitante de la Corporación local conforme a lo establecido por ésta.

c) La autorización del Ministerio de Industria para el establecimiento de las instalaciones radioeléctricas — por ejemplo, las de telefonía móvil— está condicionada por el cumplimiento de las disposiciones vigentes en materia de ordenación del territorio, medio ambiente u otro que resulte de aplicación así como de la obtención de los consiguientes permisos y autorizaciones que aquéllas prevean.

d) Por lo demás, hay que tener en cuenta que con carácter general, y por aplicación del art. 84.3 LBRL, las intervenciones de la Administración estatal de las telecomunicaciones (así, la aceptación por la CMT de las notificaciones de los operadores para poder llevar a cabo su actividad y obtener la condición de operador, al cabo una autorización reglada), con los derechos que a esa condición conecta la LGTEL, no eximirán a sus titulares de obte- 
ner las autorizaciones y licencias que deban otorgar las Corporaciones locales en virtud de sus competencias (aunque el ejercicio de éstas no puedan menoscabar la aplicación de la legislación de las telecomunicaciones en cuanto legislación sectorial, tal y como recuerda ese mismo art. 84.3 LBRL, y deba atemperarse a los criterios de armonización establecidos por la LGTEL y que ya hemos considerado).

e) En todo caso, por ello mismo, y en ese contexto, la posible intervención de los entes locales en ejercicio de competencias - regulatorias o de limitación- concurrentes en el campo de las telecomunicaciones queda así remitida a lo que la competencia sustantiva de aquellos reconocida por el ordenamiento general permita.

Como es sabido, los entes locales — los municipios—, además de sus competencias como titulares de dominio público, tienen reconocida la potestad para intervenir sobre las actividades de los ciudadanos mediante ordenanzas y bandos y someter aquéllas a previa licencia (art. 84.1 LBRL), exigencia ésta que el RSCL contempla con carácter general para obras, instalaciones y servicios (art. 5,9 y 13). Lo que permitirá el control preventivo por parte de los Ayuntamientos sobre el establecimiento de las infraestructuras y redes de telecomunicaciones (e incluso de la prestación de los servicios en su ámbito territorial). La cuestión estriba, no obstante, en si a tal fin aquéllos disponen del correspondiente título material de competencia. En este sentido, el art. 25 LBRL incluye en el listado de competencias de los municipios algunas conectables al supuesto que nos ocupa: «protección del medio ambiente» (art. 25.2.f); «ordenación, gestión, ejecución y disciplina urbanística» (art. 25.2.d); y «protección de la salubridad pública» (art.25.2.h), etc. Pero, como es sabido, el alcance concreto de ese listado competencial queda condicionado por lo que la correspondiente legislación sectorial estatal o autonómica establezca (art. 25.3 LBRL).

Pues bien, hoy por hoy (nos referiremos luego a determinadas posibles novedades futuras) no puede decirse que la legislación sectorial reguladora de las citadas materias se muestre en exceso generosa en el reconocimiento de una competencia a las Corporaciones locales que directamente pudiera fundamentar el control preventivo específico por éstas sobre las infraestructuras y actividades del sector de las telecomunicaciones. De ahí que las iniciativas de las Corporaciones locales adoptadas en los últimos años para afrontar la cuestión acabaran sustanciándose, una vez que tras una primera fase ciertamente dubitativa se concretaron ya en las correspondientes ordenanzas, al amparo de títulos materiales abstractos y preferentemente el de urbanismo (en algunos casos bajo previsiones concomitantes de una normativa autonómica fragmentaria $)^{18}$.

\footnotetext{
${ }^{18}$ En materia de medio ambiente, no existe una norma estatal mínimamente enjundiosa que lo permita, y en las competencias reconocidas a los entes locales por la legislación de las Comunidades Autónomas (reguladoras del ruido, vibraciones, contaminación del aire, etc.) dudosamente podría alojarse el
} 
Lo sucedido respecto de las instalaciones radioeléctricas, en particular las de la telefonía móvil, es ejemplo prototípico al respecto. De hecho la expansión de las estaciones de telefonía móvil en el entorno urbano se produjo inicialmente sin el adecuado control por las Corporaciones locales (en muchos casos sin permiso o licencia municipal de obra, actividad o apertura alguna) hasta que tras algunos sucesos conocidos (la eventual incidencia de dichas instalaciones en varios casos de cáncer en un colegio de Valladolid) se dispararon las solicitudes de licencia municipal por los operadores o la adopción por algunos Ayuntamientos de soluciones drásticas (cierre de las instalaciones sin licencia o la suspensión de las otorgadas).

Ante tal tesitura, ese control municipal preventivo se planteó inicialmente problemático en cuanto al título competencial utilizable al respecto; al supuesto desempeño por los operadores de un servicio público; o a que ese control pudiera tener lugar sin una ordenanza municipal específica previa. En todo caso hoy, respecto del primer punto, y tras la LGTEL de 2003, queda clara la necesidad de que el operador se sujete a la normativa local que articule los correspondientes títulos competenciales (urbanismo, medio ambiente, salud pública), en esencia, el primero. Fue en efecto el título de urbanismo el aceptado por los tribunales en los primeros recursos presentados por los operadores ante el cierre municipal de sus instalaciones sin licencia, y ha sido desde entonces el fundamentalmente invocado por los entes locales, incluso para instrumentar objetivos ambientales y de protección de la salud (algo deducible ya del propio Real Decreto 1066/ 2001, cuyos límites de protección vinculantes no excluían los adicionales que pudieran fijar los entes locales $)^{19}$. La segunda cuestión quedaría resuelta si pensamos que el estatus del operador de telecomunicaciones no es el de un concesionario de servicio público (al no ser las telecomunicaciones ya un servicio público en sentido estricto, sino una actividad liberalizada y prestada en virtud de la mera iniciativa privada), estatus que no se ve alterado porque pueda tener impuestas «obligaciones de servicio público», al cabo jurídicamente cargas en el desarrollo de una actividad no publificada y no el producto de una concesión traslaticia desde la Administración. Mayor relevancia podría tener, sin embargo, el que los títulos de intervención en este sector por parte de la Administración local no estuvieran específicamente establecidos y articulados normativamente, al menos a través de la oportuna ordenanza municipal, solución ésta que por ello mismo auspiciada por la FEMP, finalmente se ha generalizado.

\footnotetext{
control preventivo sobre las infraestructuras y servicios de telecomunicaciones. De hecho la norma que con mayor holgura podría permitir ese alojamiento es la Ley General de Sanidad de 1986 que atribuye a los entes locales como responsabilidad mínima «el control sanitario del medio ambiente» de «industrias, actividades y servicios...de edificios y lugares de vivienda y convivencia humanas, especialmente...escuelas» (previsiones éstas en su caso a integrar con las del dudosamente aplicable de modo directo RAMINP).

${ }^{19}$ Es el caso, por ejemplo, de la Ordenanza municipal reguladora de las condiciones urbanísticas de instalación de equipos de radiocomunicación del Ayuntamiento de Málaga, de 31 de enero de 2002.
} 
La complejidad de los posibles títulos habilitantes y su invocación por los entes locales para fundamentar su actividad regulatoria y de control preventivo sobre la actividad de telecomunicaciones, y que lo expuesto evidencia, es lo que sin duda ha justificado que norma tan reciente como la Ley 1/ 2006, de Régimen Especial del municipio de Barcelona, haya precisado de modo expreso y directo su atribución de modo específico a dicho municipio en el contexto, en efecto, de su competencia urbanística, estableciendo en su artículo 13: «El Ayuntamiento de Barcelona participará en la ordenación del proceso de despliegue de la red de telecomunicaciones en su término municipal, y determinará las áreas más óptimas de emplazamiento, concretando los puntos idóneos de ubicación mediante un estudio de detalle, previo acuerdo con los operadores. La instalación de antenas de cualquier tipo estará sujeta a licencia urbanística municipal. La concesión de dichas licencias se ajustará a lo previsto por el planeamiento urbanístico y las ordenanzas municipales. El establecimiento de redes civiles en zonas previamente definidas como de seguridad radioeléctrica requerirá autorización previa del Ministerio de Defensa».

\section{LA ADMINISTRACIÓN LOCAL Y LA GARANTÍA DE LOS DERECHOS DE LOS USUARIOS DE TELECOMUNICACIONES}

Junto a la acción de las Administraciones locales como operadores de telecomunicaciones o como reguladores concurrentes de las actividades del sector, en particular de las infraestructuras, podríamos plantearnos, en fin, el papel que aquéllas puedan cumplir en garantía de los derechos a prestaciones de su colectividad, en particular en lo que respecta al mínimo básico que trata de asegurar el servicio universal.

En principio, el máximo de posibilidades de dicha garantía podría pasar, claro está, por la propia prestación de los servicios, de determinados servicios de telecomunicaciones por las Corporaciones locales, actuando éstas como «operadores» (en régimen de libre competencia, aunque con los matices expuestos), incluso en su caso en virtud de su designación como responsables del servicio universal en una zona, para uno u otro elemento del mismo, etc., en virtud de la correspondiente licitación pública, algo que, como hemos visto, la LGTEL posibilita en las condiciones ya comentadas páginas atrás.

Bien es cierto que el RESERVICIOS, al admitir la posibilidad de prestación por los entes locales de servicios sin contraprestación económica abre así una dialéctica de interés para los entes locales que optaran por ese tipo de iniciativas: la prestación «gratuita» - aunque con cargo a los presupuestos municipales - de servicios no impuestos como servicio universal, sino de régimen general, pero que al cabo vendrían de facto a cumplir tal misión, versus la hipótesis de su desarrollo como operador del servicio universal designado a tal fin y con el consiguiente derecho a financiación externa (una 
LA REGULACIÓN DE LAS TELECOMUNICACIONES Y LA ADMINISTRACIÓN LOCAL

alternativa para cuya resolución resultaría, como es lógico, determinante el que el servicio universal fuera objeto de una efectiva financiación institucional externa).

Por otra parte, las Administraciones locales están lógicamente legitimadas para exigir ante la autoridad estatal de supervisión —el Ministerio de Industria - el adecuado cumplimiento por el operador de que se trate, en su caso el del servicio universal, de sus correspondientes obligaciones, todo ello en los términos expuestos más atrás.

En fin, las Administraciones locales, en cuanto Administraciones territoriales (es dudoso que los operadores públicos locales de telecomunicaciones con forma instrumental de personificación pudieran conceptuarse de tales) ya vimos disponen, conforme a la LGTEL, de una legitimación específica para iniciar el procedimiento conducente a que en caso de incumplimiento de sus obligaciones de servicio público, y por tanto del servicio universal, por parte del operador concernido, el Gobierno acuerde la asunción excepcional y transitoria por la Administración del Estado de la gestión directa de la correspondiente red o servicio de telecomunicaciones o su intervención. Ello siempre que dicho incumplimiento afecte a la garantía de la seguridad pública de competencia de dicha Administración local o cuando por el mal funcionamiento de dicha red o servicio de telecomunicaciones se vea afectada la prestación de los servicios públicos propios de la competencia de dicha Administración local, entendiendo por tales servicios públicos locales cualquier actividad de esa Administración local realizada por ésta en ejercicio de sus competencias legalmente atribuídas.

Pero, junto a lo anterior, ya hemos visto que lo previsto en la LGTEL acerca de los derechos de los usuarios finales de los servicios de telecomunicaciones no excluye la aplicación de la legislación general de defensa de los consumidores y usuarios (art. 38.8 LGTEL), un vasto conjunto normativo éste presido por la Ley estatal 26/ 1984, General para la Defensa de los Consumidores y Usuarios (LCU).

La LCU consagra el derecho de los usuarios a la protección de sus legítimos intereses económicos y sociales, en especial frente a las cláusulas abusivas de los contratos, a la indemnización de los daños y perjuicios sufridos, a la información sobre los productos y servicios, a la representación de sus intereses, y a la protección jurídica, administrativa y técnica en las situaciones de inferioridad, subordinación o indefensión. Derechos estos que serán protegidos prioritariamente cuando guarden relación directa con productos o servicios de uso común, ordinario y generalizado (art. $\left.2^{\circ} \mathrm{LCU}\right)$.

Desde este punto de partida, la LCU atribuye determinadas funciones y facultades a los poderes públicos y Administraciones públicas, entre ellas, las Corporaciones locales (téngase en cuenta que éstas tienen atribuída por el art. 25.2.g LBRL competencia, en los términos de la legislación sectorial es- 
tatal o autonómica, en «la defensa de los consumidores y usuarios»). Así, organizar actuaciones programadas de control de calidad, especialmente en relación con aquellos productos y servicios de uso común, ordinario y generalizado, y los que sean objeto de reclamaciones o quejas (art. 6 LCU); disponer de legitimación para ejercer la acción de cesación de las cláusulas abusivas de los contratos (art. 10 bis y ter LCU); coadyuvar a la satisfacción del derecho de los usuarios a la información, en su caso, a través de las Oficinas Públicas de Información de los usuarios (ostentando éstas las funciones previstas por el art. 14 LCU: información sobre los derechos de los consumidores, recepción de quejas y reclamaciones y su remisión a las entidades y órganos correspondientes, atención y defensa de los intereses de los consumidores, recabar la oportuna información de los organismos públicos y servir de apoyo y/o sede al sistema arbitral instituido por la propia LCU).

Destaca en el sistema de defensa de los consumidores y usuarios de la LCU, además de la atribución con carácter general a los poderes públicos de la adopción de medidas para la defensa de aquellos (art. 23), la atribución a las Corporaciones locales de la promoción y desarrollo de esa protección y defensa en el ámbito de su competencia, de acuerdo con la legislación estatal y autonómica (art. 41); la institucionalización de un sistema arbitral (vinculante para las quejas y reclamaciones que se interpongan, sin perjuicio de la protección administrativa y judicial) articulado a través de los órganos de arbitraje de composición representativa y plural (incluída la de la Administración en el ámbito de sus competencias) que constituyen las Juntas Arbitrales de Consumo, en especial las de ámbito autonómico y local.

Como ya hemos expuesto, tanto en el plano sustantivo (derechos) como en el instrumental de su protección (Juntas Arbitrales de Consumo), este régimen de protección de los consumidores y usuarios se imbrica con el específicamente previsto por la LGTEL en los términos ya analizados, y su refuerzo (a partir de la voluntad de las Comunidades Autónomas, competentes en materia de consumo, por reforzar su alcance y cumplimiento) podría constituir un importante complemento, si no un mecanismo de efectivo reemplazo, para solventar las disfunciones que los mecanismos de protección de la estricta regulación de las telecomunicaciones en su caso dejaran al descubierto.

\section{UN APUNTE SOBRE ALGUNAS POSIBLES NOVEDADES DE FUTURO}

Debemos finalmente completar lo hasta aquí expuesto con un apunte sobre algunas posibles novedades de orden normativo que el futuro podría depararnos tanto en la regulación de las telecomunicaciones como en el papel a cumplir en el sector por las Corporaciones locales. 


\section{La revisión del marco regulatorio de las telecomunicaciones}

La regulación de las telecomunicaciones - la de nuestro país y, como condicionante de ésta, la de la Unión Europea - ya dijimos es expresión del proceso hacia su liberalización iniciado en torno a 1990 y que consolidó en lo que podríamos llamar su $1^{a}$ fase en 1998. Todo ello con objetivos bien definidos: el logro del mercado interior (para lo que la antigua publificación era una rémora) y su desarrollo en competencia efectiva con el fin de acompasar e impulsar los necesarios cambios económicos ante las transformaciones tecnológicas.

Esa $1^{\text {a }}$ fase —de la que fue expresión nuestra LGTel de 1998- estuvo presidida lógicamente por la transición desde el antiguo modelo de monopolio, modelo que no pudo menos que dejar su huella en el nuevo modelo regulatorio. En lo jurídico, en las técnicas de intervención administrativa, todavía «ex ante» (como las autorizaciones generales y las licencias individuales previstas por la LGTel de 1998) y no en escasa medida trasunto de las tradicionales en el anterior modelo público monopolista (dado el carácter cuasi concesional de dichas licencias) y en el papel preponderante reconocido - como operador dominante y responsable del servicio universal- al viejo operador monopolista. Y en lo estructural, en el seguidismo por ese nuevo marco normativo de la estructura real que el sector presentaba en esos momentos (protagonismo de la banda estrecha y el servicio telefónico fijo y de dicho operador monopolístico, frente al todavía incipiente desarrollo de otros servicios -móvil, datos, etc.- y otros operadores). Aunque ello no impidiera la puesta en práctica del objetivo central del nuevo marco jurídico: la instauración de un modelo de competencia efectiva en las redes y los servicios de telecomunicaciones, con la consiguiente aparición de nuevas redes y servicios concurrentes con los del primer operador antes monopolístico (y el paralelo logro - como resultado tangible de tal modelo- de la multiplicación de los servicios y la mayor asequibilidad de los precios).

En la $2^{\mathrm{a}}$ fase (iniciada con el «marco regulatorio europeo» de 2000 , y de la que es expresión la vigente LGTEL de 2003), la Unión Europea y los Estados miembros bajo su impronta, tratan de profundizar en esos mismos objetivos - la liberalización, la competencia efectiva-, para consolidarlos y ganar así la apuesta no del todo lograda en la práctica (se ha dicho que lo realmente acontecido bajo el marco regulatorio de 1998 fue diferente de lo previsto porque las autoridades políticas y reguladoras nacionales pusieron más empeño en la reducción de los precios que en el desarrollo del modelo de competencia efectiva, lo que condujo a la infravaloración de los activos, a un parón en la inversión y con ello de la auténtica competencia) ${ }^{20}$. Elemento central de ese nuevo marco regulatorio comunitario de 2000 y de nuestra

\footnotetext{
${ }^{20}$ José Luis MаснотА, «El mercado de las telecomunicaciones y la regulación, ¿una brecha creciente?», BIT, núm.153, octubre-noviembre 2005, p. 8 .
} 
LGTEL de 2003 es la sustitución de la intervención administrativa «ex ante» del modelo de 1998 por la «ex post», tanto en el acceso a la explotación de redes y prestación de servicios (por la sustitución de las autorizaciones y licencias por la mera notificación a la CMT), como en el control del desarrollo en competencia del sector (a través, como instrumento capital, de la definición y análisis de los mercados de referencia y la imposición a los operadores con poder significativo de determinadas obligaciones con el fin precisamente de corregir las situaciones de ausencia de competencia efectiva en dichos mercados).

Pues bien, no cabe descartar que en el futuro la Unión Europea pueda de nuevo innovar el actual marco regulatorio de las telecomunicaciones. De hecho está previsto que a lo largo de este año 2006 tenga lugar la revisión del mismo con el fin de detectar sus aspectos no funcionales que en su caso debieran modificarse. Y ciertamente no son de escasa entidad los argumentos para esa posible revisión futura que, en su caso, podría dar lugar a una $3^{\text {a }}$ fase en el proceso. Así, que el citado instrumento capital del actual marco regulatorio (la definición y análisis de los mercados de referencia) no ha sido ultimado en términos satisfactorios en los distintos Estados miembros; la existencia en dicho marco o en la actuación de las autoridades nacionales para su puesta en práctica de ciertos lastres que lo perfilan todavía como un modelo de transición o, es más, expresivo de un neointervencionismo regulatorio, en especial por la conversión del análisis de los mercados de referencia en un burocratizado sistema de intervencionismo público mucho más inconveniente en cuanto antinómico - por la fragmentación en diferentes mercados en que se basa - con el paradigma de la convergencia ya dominante; o, en fin, la falta de ajuste de fondo del marco regulatorio a la evolución del sector.

Se viene subrayando en este sentido que la actual situación real y sobre todo la tendencial del sector (banda ancha, neutralidad tecnológica, convergencia multisectorial y multiservicios - como ejemplo, el futuro despliegue de las «Next Generation Networks», NGN, infraestructuras que facilitarán la generalización de servicios y aplicaciones convergentes — así, Voz sobre IP, «Internet Protocole», o TV-IP_, con su incidencia en la difuminación de los distintos mercados de telecomunicaciones) conforman un horizonte bien distinto para el que (al hilo de la comentada revisión del actual marco regulatorio comunitario de 2000) se auspicia debería establecerse ya un definitivo marco regulatorio estable, que garantice el desarrollo de un modelo de competencia efectiva, con el mínimo de intervención pública regulatoria y el máximo de garantía para los usuarios finales ${ }^{21}$. Otra cosa es que estos auspicios - en general por parte de los agentes del sector- se vean confirmados (como piedra de toque el debate - conceptual y tras él el económico y empresarial- sobre si la comunicación oral por Internet, VozIP, cuyo desarrollo se prevé imparable como hipotética alternativa a la

${ }^{21}$ Gretel, «Ante la revisión del marco regulatorio de las comunicaciones electrónicas», BIT, núm.155, febrero-marzo 2006. 
telefonía actual, es o no telefonía, y consecuentemente ha de ser o no regulada).

\section{La reforma de la legislación básica de régimen local y las re- formas estatutarias}

Pero también en el ámbito del ordenamiento local podríamos encontrarnos con algunas futuras novedades de interés. En efecto, como es sabido, la actual delimitación de las competencias de las Corporaciones locales, en concreto de los municipios, establecida en la LBRL ${ }^{22}$, ha venido siendo objeto de crítica en los últimos años al paso de la reivindicación por aquéllas de un más denso y sobre todo claro marco de competencias. Expresa tal reivindicación en la dialéctica del llamado «Pacto Local», puede de alguna manera reconocerse también en el «Libro Blanco para la reforma del Gobierno Local» publicado en 2005 por el Ministerio de Administraciones Públicas. El panorama que dibuja el Libro Blanco es rotundo: los entes locales no tienen hoy prácticamente atribuídas unas competencias expresas al quedar las mismas condicionadas por la legislación sectorial, e incluso las directamente atribuídas por la Ley básica — los servicios obligatorios del art. 26.1 LBRL_se conciben legalmente como de mera prestación y no como un ámbito competencial completo en mano local. Su propuesta no es menos rotunda: las competencias locales deben estar atribuídas expresamente y ser plenas y completas (incluyendo el Libro Blanco en su propuesta la atribución a los municipios de competencia en materia de «telecomunicaciones y sociedad de la información»).

Pues bien, recogiendo en gran medida las líneas del «Libro Blanco», el Anteproyecto de nueva Ley básica sobre el Gobierno y la Administración Local actualmente en elaboración, perfila las competencias de los entes locales — de los municipios - sobre bases novedosas conforme al siguiente esquema de cláusulas de atribución (esquema que, por lo demás, se ha plasmado ya parcialmente, a modo de anticipo, y como vamos a ver, en alguna norma positiva ya vigente como es la reciente Ley 1/ 2006, de 13 de marzo, por la que se regula el Régimen Especial del municipio de Barcelona).

1) Reconocimiento de una competencia general, pero expresamente residual, «en todas las materias que sean de interés local y que no estén atribuidas por la legislación al Estado o a las Comunidades Autónomas» ${ }^{23}$.

\footnotetext{
${ }^{22}$ Conforme a este cuadro: además de las competencias complementarias (art. 28) o que ejerzan por delegación (art. 27), una capacidad general (art. 25.1), específicamente concretada en las competencias que en virtud del principio de participación competencial les atribuya la legislación sectorial estatal o autonómica (art. 25.2) y en los llamados servicio mínimos u obligatorios (art. 26).

${ }^{23}$ Esta cláusula y con dicho alcance puede reconocerse ya en el artículo $3^{\circ}$ de la citada Ley de Régimen Especial de Barcelona: «Cláusula general de competencias. El Ayuntamiento de Barcelona podrá promover toda clase de actividades y prestar todos los servicios públicos que contribuyan a satisfacer
} 
2) Atribución legal expresa y específica por la propia Ley básica de competencia en un listado de materias cuyo ejercicio por los municipios se efectuará «en el marco de» la legislación sectorial estatal o autonómica.

El listado incorpora, junto a alguna de las materias hoy recogidas en el artículo 25.2 LBRL, otras nuevas (por ejemplo, «regulación y autorización del establecimientos de actividades económicas y empresariales en su territorio», «desarrollo de la economía local»), y a las que podrán añadirse y con el mismo alcance de la cláusula, las que los Estatutos de las Comunidades Autónomas les atribuyan. Pero la novedad determinante es su atribución directa por la Ley básica, y no como lo son ahora las del art. 25.2 LBRL que están estrictamente condicionadas a «los términos de» la legislación sectorial.

3) Atribución de los llamados «servicios obligatorios locales», un expreso listado que podrá además enriquecerse con los que les atribuyan los Estatutos de Autonomía. La cláusula parece un trasunto del actual art. 26 LBRL, pero tiene muy diferente contextura, pues incluye no sólo actividades prestacionales sino también regulatorias, incluso funciones.

4) Materias competencialmente garantizadas a los entes locales en las que la legislación sectorial deberá atribuir competencias a los municipios («Las leyes del estado y de las Comunidades Autónomas deberán delimitar los intereses locales en las siguientes materias...atribuyendo a los municipios competencias propias»). En este caso es la ley sectorial la que efectuará la atribución específica, pero queda vinculada a hacerlo, siendo en esta cláusula donde, en efecto, el Anteproyecto recoge la materia «telecomunicaciones y servicios de la sociedad de la información ${ }^{24}$.

las necesidades de los ciudadanos que no estén expresamente atribuídas a otros Administraciones públicas. Asímismo, podrá llevar a cabo actividades y servicios complementarios a los desarrollados por la Administración estatal y autonómica».

Por lo demás, dicha Ley especial de Barcelona proclama expresamente con carácter previo, en su artículo $2^{\circ}$. 1, la autonomía municipal en estos términos: «De acuerdo con la autonomía garantizada constitucionalmente a los municipios, lo previsto en el Estatuto de Autonomía de Cataluña y lo establecido en la Carta Europea de Autonomía Local, se reconoce al Ayuntamiento de Barcelona el derecho y la capacidad efectiva para ordenar y gestionar los asuntos públicos que afecten a sus ciudadanos, en el marco del ordenamiento jurídico, bajo su propia responsabilidad y en beneficio de sus habitantes» (a tener en cuenta, a efectos interpretativos, esa contextualización del precepto en el ámbito delimitado por la Carta Europea, pero también que es una autonomía cuyo alcance competencial está supeditado a lo que establezca el ordenamiento jurídico, por tanto el ámbito definido por la propia Ley Especial de Barcelona, más —ex art. $1^{\circ} .4$ de ésta- lo permitido por la LBRL).

${ }^{24}$ Como anticipo particular y ya vigente de esta cláusula, la Ley 1/ 2006, de Régimen Especial de Barcelona, establece en su artículo $2^{\circ} .2$ : «La presente Ley atribuye al Ayuntamiento de Barcelona, de acuerdo con su capacidad de gestión, competencias en materia de infraestructuras, dominio público marítimo terrestre, telecomunicaciones, patrimonio histórico, movilidad, seguridad ciudadana, justicia de proximidad y hacienda local» (esta Ley 1/ 2006 especifica estas competencias a lo largo de su articulado). «Asimismo y en cumplimiento de lo previsto en el artículo 2 de la Ley 7/ 1985, de 2 de abril, reguladora de las Bases de Régimen Local, la legislación sectorial del Estado atribuirá, en su caso, competencias en el ámbito de los servicios e infraestructuras que sean básicos para el desarrollo de la ciudad» (en lo que respecta a la materia telecomunicaciones ya hemos recogido a lo largo de las páginas precedentes las oportunas referencias a lo previsto por esta Ley). 
LA REGULACIÓN DE LAS TELECOMUNICACIONES Y LA ADMINISTRACIÓN LOCAL

5) Competencias por delegación o encomienda del Estado o de las Comunidades Autónomas.

6) Extensión de las competencias locales a la iniciativa pública en la actividad económica y especificación de las de ese carácter reservadas a los municipios (a modo de trasunto del actual art. 86 LBRL, aunque ampliando el ámbito competencial a otras actividades desarrolladas en concurrencia o «en reserva» y mezclándolas con los servicios obligatorios).

7) Pero junto a lo anterior, la novedad quizá más significativa es el régimen de configuración y gestión de sus servicios por las Corporaciones locales, algo que el Anteproyecto efectúa desde una nueva consideración dogmática de los servicios y servicios públicos locales.

El Anteproyecto contempla dentro de «las formas de gestión de los servicios locales» no sólo los prestados, directa o indirectamente, por los entes locales, sino también los prestados en virtud de su libre iniciativa por los particulares cuando estos servicios estén regulados, en el ámbito de su competencia, por los municipios. A todos ellos los denomina «servicios locales de interés general», y aunque distingue los prestados por los entes locales (a los que califica de «servicios públicos») y los prestados por los particulares en virtud de su libre iniciativa y sujetos a la reglamentación de la correspondiente Ordenanza (a los que califica de «servicios reglamentados»), a todos ellos les aplica una misma consideración teleológica (el servicio a los ciudadanos) y material (un mismo régimen objetivo de igualdad, continuidad, protección de los derechos de los usuarios, calidad adecuada, y precios asequibles o gratuitos para colectivos desfavorecidos).

Podría interpretarse que esta proyectada nueva regulación básica del régimen local daría pié a un cambio sustancial en el papel a cumplir por los entes locales como reguladores o prestadores de los servicios de telecomunicaciones . Sin embargo, como la actuación local —en ese abanico de posibilidades - ha de tener lugar «en el ámbito de sus competencias», conviene reparar en que la materia telecomunicaciones se recoge en el Anteproyecto en la cláusula de las materias garantizadas a los municipios pero según se las atribuya la legislación sectorial estatal o autonómica. De manera que lo previsto en la actual LGTEL - como ley sectorial y su alcance para los entes locales- podría permanecer en los términos que hemos expuesto. A menos que se considerara que las actuales previsiones de la LGTEL «no delimitan adecuadamente los intereses locales» — como exige esa cláusula del Anteproyecto- en materia de telecomunicaciones.

Las novedades en la normación básica del régimen local podrían, de otra parte, afectar — posibilitando así un mayor grado de cooperación- a los actuales órganos a tal fin, pues el Anteproyecto contempla la creación de una «Conferencia de Asuntos Urbanos» (para las ciudades de más de 250.000 habitantes), trasunto de la actual Conferencia de Ciudades, pero independiente 
de la actual Conferencia Sectorial de Asuntos Locales (donde hoy aquélla se integra) (art. 138 LBRL) y de una «Conferencia General» — no Sectorial como ahora es la Conferencia de Asuntos Locales a que se refiere el art. 120 Bis LBRL- de Política Local», sin perjuicio de la participación de los entes locales en las demás Conferencias Sectoriales ${ }^{25}$.

Pero las novedades en el ámbito competencial de las telecomunicaciones y su incidencia sobre las Corporaciones locales podrían derivar también de las reformas de los Estatutos de Autonomía en curso. Porque, eventualmente, la materia de telecomunicaciones, exclusiva del Estado ex art. 149.1.21 $\mathrm{CE}$, pudiera quedar de alguna manera reconocida a las Comunidades Autónomas (en su caso por la vía del art. 150.2 CE) ${ }^{26}$, supuesto en que, claro está, todo el actual régimen de las telecomunicaciones quedaría alterado. Y con la hipótesis de su consecuente incidencia en las competencias de los entes locales si los Estatutos reformados sobre esa base incluyeran una atribución expresa a aquéllos en la materia, o porque incluso el propio ámbito competencial de los entes locales delimitado por la legislación básica de régimen local se entendiera por algunas Comunidades Autónomas con Estatutos reformados no estrictamente aplicable con tal carácter en dichas Comunidades, a partir de alguna modulación estatutaria respecto de la aplicabilidad en esa Comunidad Autónomas de las bases estatales, precisamente en materia de régimen local $^{27}$.

\footnotetext{
25 Para completar la referencia cruzada a la reciente Ley 1/ 2006, de Régimen Especial del municipio de Barcelona, digamos que específicamente ésta ha creado una Comisión de Colaboración Interadministrativa que, integrada por representantes del Estado, la Generalidad de Cataluña y el Ayuntamiento de Barcelona, tiene como cometido realizar estudios para la mejor articulación del régimen local de Barcelona, proponer criterios de desarrollo y aplicación de dicha ley y evaluar los proyectos de colaboración entre las Administraciones representadas, así como su aplicación (a tal fin podrá proponer formas de colaboración mediante la suscripción de los correspondientes convenios) (art. $5^{\circ}$ ).

\begin{abstract}
${ }^{26}$ A título de ejemplo, la Propuesta de Reforma del Estatuto de Autonomía de Cataluña, incluía —en su texto originario- y como «competencia compartida» de la Generalidad (por tanto sujeta sólo a bases estatales), en su art. 140.12, «a) la regulación del acceso y la definición de un conjunto mínimo de servicios de acceso universal; b) la garantía de la interoperabilidad de los sistemas y de los equipos de recepción de los servicios de comunicaciones electrónicas y de los contenidos que se distribuyen y de acceso a estos servicios y contenidos; c) la ordenación, la regulación y el control de las redes de comunicaciones electrónicas», y en su art. 140.13, «la — competencia- ejecutiva en materia de gestión del espacio radioeléctrico y en el marco de la planificación de la gestión estatal, sobre las comunicaciones electrónicas dentro del territorio de Cataluña». Todo ello ciertamente a título de autointerpretación estatutaria de una transferencia de competencias de las del art. 150.2 de la CE (cf. la disposición adicional $3^{\mathrm{a}}$.1.c) de la Propuesta de Estatuto).

${ }^{27}$ La Propuesta de Reforma del Estatuto de Autonomía de Cataluña recogía en su texto originario, en su art. 160, la competencia «exclusiva» de la Generalidad en materia de régimen local, incluyendo la determinación de las competencias de los entes locales, con la previsión, por otra parte (art. 84.2. 1), como materia para la competencia propia de los entes locales de «la regulación del establecimiento de infraestructuras de telecomunicaciones y prestación de servicios de telecomunicaciones».
\end{abstract}

